Old Dominion University

ODU Digital Commons

$4-2020$

Renegotiation of Joint Venture Contracts: The Influence of Boards of Directors and Prior Ties as Alternative Governance Mechanisms

Valérie Duplat

Elko Klijn

Jeffrey Reuer

Henri Dekker

Follow this and additional works at: https://digitalcommons.odu.edu/management_fac_pubs

Part of the Business Administration, Management, and Operations Commons, and the Economics Commons 


\title{
Renegotiation of joint venture contracts: The influence of boards of directors and prior ties as alternative governance mechanisms
}

\author{
Valérie Duplat $^{\mathrm{a}, *}$, Elko Klijn ${ }^{\mathrm{b}}$, Jeffrey Reuer $^{\mathrm{c}}$, Henri Dekker ${ }^{\mathrm{d}}$ \\ ${ }^{a}$ Vrije Universiteit Amsterdam, School of Business and Economics, Department of Management and Organization, De Boelelaan 1105, 1081 HV \\ Amsterdam, The Netherlands \\ ${ }^{\mathrm{b}}$ Old Dominion University, Department of Management, 20400 Constant Hall, Norfolk, VA, 23529, USA \\ ${ }^{\mathrm{c}}$ University of Colorado, Leeds School of Business Strategy, Entrepreneurship and Operations, 995 Regent Drive, Koelbel Building, 419 UCB, Boulder, \\ CO 80309-0419, USA \\ ${ }^{\mathrm{d}}$ Vrije Universiteit Amsterdam, School of Business and Economics, Department of Accounting, De Boelelaan 1105, 1081 HV Amsterdam, The \\ Netherlands
}

\section{A R T I C L E I N F O}

\section{Keywords:}

Joint venture

Renegotiation

Board of directors

Prior ties

Incomplete contracts

\begin{abstract}
A B S T R A C T
Research on alliance governance has pointed out that joint ventures (JVs) are particularly complex forms of collaboration. Partnering firms therefore often face difficulties in anticipating contingencies and collaborative behaviors at the contract negotiation stage. When initial JV contracts are incomplete, renegotiation represents a key strategic opportunity for enhancing contractual safeguards or coordination guidelines over the course of the joint venture. Costs and risks entailed by renegotiating JV arrangements at a later stage are far from trivial, however. Existing research on alliances suggests that practitioners have alternative relational and formal governance solutions at their disposal for handling possible inefficiencies caused by contractual gaps over time. Although insightful, this research does not enable a determination as to whether these alternative relational and formal mechanisms substitute for or facilitate ex post contractual renegotiation. The competing arguments found in the literature provide little guidance to JV practitioners as well. Our results show that the collaborative context within which the JV is embedded (i.e., prior inter-partner ties) obviates the need for enhancing incomplete JV contracts ex post. By contrast, ex post contractual adjustments are fostered and facilitated by the formal and administrative apparatus engaged over the course of the JV (i.e., an involved JV board of directors). Such opposing effects suggest that prior ties can "prevent" the occurrence of inefficiencies caused by contractual gaps, while an involved JV board primarily can act as a mediation and renegotiation platform to "repair" the exchange when inefficiencies occur. Our findings highlight the multidimensional nature of joint venture governance, and in particular the interplay among various formal and informal governance solutions in the execution of joint ventures. By unpacking their complex effects on the decision to renegotiate incomplete JV contracts, our study also holds important value for managers seeking to govern their JVs over time.
\end{abstract}

\section{Introduction}

Renegotiating contractual arrangements is a key strategic option for firms engaged in joint venture (JV) collaborations.

\footnotetext{
${ }^{*}$ Corresponding author.

E-mail address: v.duplat@vu.nl (V. Duplat).
} 
Renegotiation enables managers to adjust JV contracts ex post when initial uncertainties concerning the collaboration and its broader context diminish. JVs are indeed complex transactions (e.g., Beamish and Inkpen, 1995; Luo, 2007; Oxley, 1997). Partnering firms may not possess the information needed to craft appropriate and "complete" contracts at the outset of the JV (e.g., Chi, 1994; Hennart, 1988; Lyons, 1991). Furthermore, even when a wide range of contingencies is anticipated by the partners, the costs of negotiating safeguards for addressing them can be prohibitive (Anderson et al., 2017; Crocker and Reynolds, 1993). JV partners may then, intentionally or unintentionally, start collaborating with incomplete contracts (Crocker and Masten, 1991; Saussier, 2000). In this context, renegotiation represents a critical means to alleviate possible moral hazards and inefficiencies caused by contractual gaps. It offers the opportunity to enhance the contractual safeguards and to further delineate and specify coordination guidelines over the course of the JV collaboration (Ariño et al., 2008; Reuer and Ariño, 2002). Suitable contractual safeguards can reduce opportunistic behaviors by increasing transparency, improving monitoring, and clarifying rights and duties. They facilitate the demonstration of non-compliance and its penalization (Carson et al., 2006; Parkhe, 1993), and they enable partners to align their respective interests (Hart and Holmstrom, 1987; Kumar and Seth, 1998). Proper contractual arrangements can also ease the coordination of tasks and efforts among partners by specifying explicit ways to communicate and to exchange information (Argyres and Mayer, 2007; Faems et al., 2008). Thus, renegotiation is an ex post remedy apt to reduce firms' vulnerabilities to problems in managing their JV over time.

In spite of the potential governance benefits offered by renegotiating incomplete contracts, allying partners do not systematically engage in adjusting contracts over the lifespan of their collaboration. This observation tends a priori to run against the "discriminating alignment" precept forwarded by transaction cost economics (TCE). Contractual renegotiation should indeed be seized as an opportunity to suitably align ex post initial contractual terms with the transaction and exchange attributes at hand (Williamson, 1991). In order to understand this renegotiation decision, our study builds upon existing research that unveils the key role played by alternative governance mechanisms in helping JV partners alleviate opportunism and foster collaboration. In the JV setting in particular, two alternative mechanisms have been shown to significantly affect the management of inter-partner collaboration: relational governance gained from prior inter-partner collaborations (e.g., Gulati, 1995; Zollo et al., 2002) and the involvement of the JV board of directors, which corresponds to a formal and deliberate mechanism developed and used over the lifespan of the JV (e.g., Killing, 1983).

Both mechanisms should shape partners' decisions to enhance incomplete contracts as they are expected to influence the two main determinants at the root of the renegotiation decision trade-off: (1) the inefficiencies caused by the incompleteness of the JV contract, and (2) the risks and costs associated with renegotiation. On the one hand, as explained above, renegotiation of incomplete contracts should be favored as it enables partners to mitigate possible inefficiencies and collaboration failures implied by contractual incompleteness. Initial contracts are then altered as the collaboration proceeds and information is obtained about the JV's challenges and needs (Bleeke and Ernst, 1991). On the other hand, the renegotiation process itself induces risks and costs that are far from trivial (Ariño et al., 2008; Gil, 2009). Non-negligible time as well as important human resources and legal expertise may have to be devoted to the renegotiation process. Moreover, renegotiation can put the collaboration in jeopardy as it may be perceived as a manifestation of distrust or suspicion (Ghoshal and Moran, 1996; Malhotra and Murninghan, 2002). This is particularly true when the renegotiation aims at expanding the JV contract. ${ }^{1}$ Given the uncertainty under which renegotiation takes place (Ariño et al., 2008; Gil, 2009), firms must be selective in ex post adjustments of their contracts and balance expected risks and costs of renegotiation with inefficiencies caused by less exhaustive contractual arrangements.

Although we can infer from previous research that relational governance resulting from prior inter-partner interactions and formal administrative apparatus implemented ex post should impact the renegotiation decision trade-off, the insights offered by theoretical and empirical studies present alternative explanations of how these governance mechanisms might affect contract renegotiation. By offering collaboration support, prior ties and an involved JV board of directors could mitigate the inefficiencies resulting from any contractual gaps; hence they could reduce the extent of contract enhancement over time. Alternatively, those same safeguards and supports provided by prior ties and an involved board can temper the risks and costs encountered by JV partners once inefficiencies are manifest. Reduced risks and costs should in turn ease contractual adjustment at a later stage. The opposing nature of those arguments found in the alliance literature on the interplay between governance mechanisms leads us to propose a set of competing hypotheses on the moderating roles played by relational remedies resulting from the inter-partner collaborative context and the alternative formal governance mechanisms developed for executing the JV (i.e., the JV board of directors). In other words, we explore the contrasting theoretical predictions that prior collaborations and an involved JV board can substitute for or facilitate the ex post enhancement of incomplete JV contracts.

Analysis of survey data on JV governance and management supports our theoretical contention that considering the interrelationship between the three governance mechanisms is essential for understanding ex post governance decisions such as renegotiation. Our findings show that prior ties reduce the extent of renegotiation of incomplete JV contracts. Repeated interactions provide "informal self-enforcing safeguards", which lessen the need for making incomplete contracts more exhaustive (Dyer and Singh, 1998; Larson, 1992). By contrast, a more involved JV board increases partners' inclination to adjust incomplete contracts. This

\footnotetext{
${ }^{1}$ Our study exclusively focuses on the extent to which contractual provisions are added or strengthened and not on the extent to which they are trimmed. The occurrence of renegotiation for trimming contracts is much lower than the one for expanding them. Given the uncertainty associated with the renegotiation process, partners may prefer to apply their overly complex contract in a loose way rather than renegotiating it (Faems et al., 2008). Also, the inefficiencies stemming from contractual over-completeness should be less significant than those caused by contractual incompleteness. As a result, our framework suits more the exploration of renegotiation decisions made for expanding or strengthening JV contracts.
} 
latter finding advances the nascent literature on JV boards by showing that rather than supplanting the need for contractual mechanisms, this administrative mechanism actually fosters and eases the adjustment of JV contracts over time.

Our study taps into and contributes to several important debates on alliances and their implementation, and also helps surface new open questions. First, our study addresses the debate concerning the usefulness of contractual governance in alliances, as it investigates the necessity of renegotiating incomplete JV contracts. Our findings serve as evidence that JV contracts continue to play a central governance role during the execution of JV collaboration. We point out particular conditions leading to different possible roles played by contractual renegotiation: a means to "repair" inefficiencies caused by contractual incompleteness or a means to "prevent" those inefficiencies. A second debate to which our study relates concerns the substitutive versus complementary nature of the relationship between contractual and relational governance (e.g., Hoetker and Mellewigt, 2009). Prior studies have widely examined this relationship at the formation stage of alliances (e.g., Hoetker and Mellewigt, 2009; Poppo and Zenger, 2002). By adopting an ex post perspective, our study offers new insights. We argue and show that while the self-enforcing governance implied by prior ties tends to reduce the inefficiencies caused by contractual gaps (e.g., Gulati, 1995) and thereby the need to renegotiate incomplete JV contracts; those ties may simultaneously facilitate the renegotiation process independent of the level of contractual incompleteness. JV partners may indeed wish to keep track of their learning about the focal JV transaction by using the contract as a repository of knowledge and information (Mayer and Argyres, 2004). Finally, critical open questions concerning the nature of the relationship between JV board governance and contractual governance surface and are addressed in this study. The JV board of directors and its influence have been barely discussed in the JV literature (e.g., Reuer and Klijn, 2018). Our results show that formal governance mechanisms developed and used ex post for executing JVs tend to address the occurring inefficiencies by making contracts more closely aligned with the transaction attributes at hand. Interestingly, this latter result provides a different perspective on the idea that JV boards act as contractual gap-fillers (Pisano, 1989; Williamson, 1991).

\section{Theory and hypotheses}

\section{Background theory: contractual renegotiation}

Contracts are key mechanisms in the governance of JVs, and partners have considerable latitude in delineating roles, performance expectations or dispute-resolution mechanisms in their contracts (Klein et al., 1978; Poppo and Zenger, 2002). Despite efforts to craft appropriate contracts, partnering firms may start collaborating, either intentionally or unintentionally, under incomplete contracts. Contingencies not anticipated at the outset of the collaboration may become obvious only when JVs start, or, even if anticipated, it would have been prohibitively costly to draft proper contractual remedies at the negotiation stage (Chi, 1994; Williamson, 1991). Although renegotiation is a strategic practice with important implications for alliance dynamics, research on alliance governance has devoted scant attention to the occurrence and drivers of contractual renegotiation. In particular, the influence of contractual incompleteness on renegotiation has received little scholarly consideration. Two studies are noteworthy, however. Reuer and Ariño (2002) and Ariño et al. (2008) show that a misalignment between exchange attributes and the choice for an equity or non-equity alliance affects the propensity to renegotiate. These two studies support the idea that firms aim to reduce the inefficiencies associated with governance misalignment by renegotiating their contract. More generally, there is substantial support for the "discriminating alignment" proposition, according to which the efficiency of an exchange will be enhanced when an alignment exists between the chosen governance structure and the fundamental attributes of the transaction and the broader contracting environment (Anderson and Dekker, 2005; Geyskens et al., 2006; Williamson, 1985). Governance structures should be chosen in a selective fashion based on efficiency considerations. In particular, firms are predicted to only devise more expansive contracts to support exchanges characterized by salient hazards (Joskow, 1988) and coordination challenges (Gulati et al., 2005). Contracts that are incomplete relative to those hazards and challenges may result in non-trivial inefficiencies over the course of the collaboration (Joskow, 1988) and possibly premature termination (Rahman and Korn, 2014). Ex post bargaining over the value of each partner's contribution and their share of the surpluses may, for instance, occur (Pisano, 1989). The prospect of such bargaining distorts partners' incentives to invest and jeopardizes the collaboration (Hart and Moore, 1988; Tirole, 1986). Incentives to undertake ex ante relationship-specific investments are then compromised (Williamson, 1975) as they weaken the bargaining position during ex post renegotiation (Hart, 1995). Similarly, when coordination provisions are underspecified relative to partner-specific interdependences, coordination failures may arise due to unstructured communication, the omission of crucial activities, or a misallocation of resources (Mayer and Argyres, 2004; Park and Ungson, 2001). Under these conditions, there is an incentive for partners to enhance their contracts to address incompleteness over time.

Specifically, contracts can be adjusted ex post to address the needs of the collaboration that might not have been contemplated at the outset, or when initial contracting costs were too prohibitive to formalize those needs in the contract. Despite the potential governance benefits offered by renegotiation, the associated risks and costs are non-negligible (Ariño et al., 2008; Gil, 2009). Existing theory suggests that alternative formal and relational governance instruments at play in the JV setting may influence the trade-off between facing possible damages and inefficiencies caused by contractual incompleteness on the one hand, and encountering the risks and costs imposed by renegotiation on the other hand. Hence, investigating renegotiation decisions made by JV practitioners entails considering the broader JV governance context. The renegotiation of the contract is embedded in the broader collaborative context of the partners as well as the other formal governance mechanisms supporting the collaboration, as we will discuss. 


\section{Formal and relational governance in the joint venture setting}

JVs have governance properties closest to those of internal organizations and they distinguish themselves from other hybrid forms notably by the setting up of a separate organizational entity with a board of directors (Pisano, 1989). The roles played by JV boards tend to differ largely from those played in unitary organizations (Reuer and Klijn, 2018). The fact that JV partners remain independent organizations raises peculiar challenges for a board as partners have similar but also dissimilar strategic intents and competitive objectives (Dussauge et al., 2004). The board helps JV partners protect, assert and enforce their rights as partial owners (Janger, 1980). Its roles encompass a non-trivial political aspect as there is a need to reduce appropriation problems (e.g., Pisano, 1989), address competitive conflicts (e.g, Geringer and Hébert, 1989; Ravasi and Zattoni, 2006), and build consensus between respective interests (Kumar and Seth, 1998; Ravasi and Zattoni, 2006). JV directors provide a direct communication link with senior management of the JV partners. They therefore permit monitoring and evaluation of counterparties' activities (Kogut, 1988; Kumar and Seth, 1998). Board members may also be entitled to independently assess financial information in addition to information acquired through direct observation (Osborn and Baughn, 1990). Veto rights over strategic decisions are often granted to directors at JV formation as well (Geringer and Hébert, 1989; Killing, 1983). The board of directors can thus actively function as a primary negotiation platform for discussing and resolving conflicting interests (Geringer and Hébert, 1989; Ravasi and Zattoni, 2006). Apart from deterring opportunism and preserving incentives, the board is a major forum in which parties can coordinate their activities (Björkman, 1995; Killing, 1983). It provides a formal and deliberately crafted arena for exchanging information, communicating and adjusting collaborative activities as contingencies surface throughout the JV collaboration (Kumar and Seth, 1998). The governance functions of boards and the intensity of their involvement may greatly differ among JVs, however (Pisano, 1989; Reuer et al., 2014).

Aside from this formal and administrative governance, relational governance has also been shown to help partners prevent and attenuate opportunism and alleviate coordination concerns in alliances (Faems et al., 2008; Gulati, 1995; Hoetker and Mellewigt, 2009; Poppo and Zenger, 2002). Contrary to the board of directors, relational governance develops in an informal way and is inherited from inter-partner interactions taking place prior to the focal JV. An important stream of literature primarily grounded in sociology has investigated the extent to which familiarity, trust, learning and social networks subsumed under relational governance offer control or coordination benefits in collaborative exchanges (Gulati, 1995). This stream of literature has extensively investigated the interplay between contractual and relational governance (e.g., Faems et al., 2008; Hoetker and Mellewigt, 2009; Poppo and Zenger, 2002). Theoretical predictions as well as empirical results vary widely, however (e.g., see Cao and Lumineau, 2015 for a recent literature review). Some scholars argue that, as a consequence of inter-partner familiarity, trust, learning and the development of collaborative routines, prior ties alleviate the need for costly contracts and substitute for formal governance (e.g., Gulati and Singh, 1998; Uzzi, 1997). Others posit that both mechanisms reinforce each other and act as complements (e.g., Poppo and Zenger, 2002; Ryall and Sampson, 2009; Solís-Rodríguez and González-Díaz, 2018).

Regarding the interplay between contractual structures and the JV board of directors, theoretical and empirical research remains scarce (e.g., Klijn et al., 2013; Reuer et al., 2002). Pisano (1989) and Williamson (1991) emphasize the gap-filling role played by the board during JV implementation and suggest a substitutive relation. It is not clear, however, whether an involved JV board of directors fills in these gaps or whether it facilitates contractual adaptations owing to the monitoring or other functions that it fulfills. Given the contrasting nature of those effects and the mixed insights obtained from the extant theoretical and empirical literature, it is difficult to predict a priori how both of these alternative mechanisms influence partners' responses to contractual incompleteness during JV implementation. These contradicting theoretical arguments provide practitioners with little guidance concerning the renegotiation of JV contracts, and they result in a set of competing hypotheses. Our hypotheses support alternatively a substitution versus facilitation effect on the expansion of incomplete JV contracts, and our aim is to unpack the interplay of alternative governance mechanisms during JV implementation.

\section{Hypotheses development}

\section{Prior ties and contractual renegotiation}

Repeated collaborations between firms reflect the extent of their relational governance offered by the cooperative context of a given partnership. Prior studies have highlighted the multidimensional nature of relational governance gained from prior collaborations and, accordingly, we account for its subsumed dimensions when developing our first two moderating hypotheses: calculative and non-calculative trust, partner-specific routines and learning (Gulati and Sytch, 2008; Mellewigt et al., 2017; Vanneste and Puranam, 2010). Most scholars agree that trust becomes important in situations characterized by risk and uncertainty (Das and Teng, 1998; Zaheer et al., 1998). Contractual gaps and the renegotiation process typically bring salient uncertainties into JV collaborations. The positive effect of prior ties on inter-partner trust is intuitive and widely relied upon in prior research (e.g., Gulati, 1995; Uzzi, 1997). Trust entails the expectation that allying partners can be relied on to fulfill their obligations to behave in a predictable manner and to act fairly even when the possibility of opportunism is present (Gulati, 1995; Zaheer et al., 1998). In order to grasp how trust can potentially reduce the inefficiencies caused by contract incompleteness and so influence the renegotiation trade-off, calculative and non-calculative elements of trust are considered (McEvily et al., 2003; Rousseau et al., 1998). The calculative component of trust reflects confidence in another partner's reliability and predictability in a sense that the damages experienced from a breach of trust would exceed the gains from behaving opportunistically (Ring and Van de Ven, 1992) and the rewards for being trustworthy are more attractive than the gains from self-seeking behaviors (Lewicki and Bunker, 1996). Prior ties contribute to stronger prospects of future collaboration and benefits (Poppo et al., 2008), thereby creating a shadow of the future. In this regard, economists emphasize the anticipation of valuable future interactions in ensuring cooperation in the present setting (Fudenberg et al., 1994; Radner, 1986). By 
opting for dilatory tactics and taking advantage of contractual gaps, JV partners would risk the loss of idiosyncratic and collaborative routines they developed over time and the loss of future trade value (Pisano, 1989). By opting for complying behaviors instead, partners benefit from the specific and exclusive insights into their counterparts in terms of compatibility of goals, quality standards, aspirations and short-term and long-term business plans and goals (Dyer and Singh, 1998; Harrison et al., 2001).

Besides calculative trust, prior ties also boost non-calculative trust. Repeated interactions facilitate the identification with the JV partner (Lewicki and Bunker, 1996). As a result of those interactions, parties tend to adhere to collectively-shared values and to develop a shared identity and strategic goals in a cooperative manner (Poppo et al., 2016). Collective benefits are ultimately valued above any self-gains. Overall, the trust-generating context that is developed through successive interactions is likely to preclude the emergence of inefficiencies caused by "intentional" incomplete contracting. It can also mitigate inefficiencies explained by "unintentional" sources of incomplete contracts such as bounded rationality (Williamson, 1991). ${ }^{2}$

At the same time, repeated interactions enable the partners to learn about each other's internal structures and decision-making styles (Doz, 1996). They can over time develop partner-specific routines such as routines related to information sharing (Cyert and March 1963; Zollo et al., 2002). Routines store experiences of "how things are done", which operate like mutually accepted heuristic guidelines of what actions are to be taken in a specific situation (Feldman and Rafaeli, 2002; Nelson and Winter 1982; Felin et al., 2012). These established and refined routines as well as the overall first-hand information learned from prior exchanges enhance the understanding of individual and mutual activities beyond contractual gaps. They thus enable partners to mitigate the occurrence of inefficiencies caused by those contractual gaps. They also allow partners to be more flexible concerning contract application (Anderson et al., 2017). The necessity to buttress incomplete contracts through renegotiation diminishes as a consequence. These arguments give rise to our first Hypothesis:

Hypothesis 1a. Prior ties between partners weaken the association between JV contractual incompleteness and the ex post expansion of contractual safeguards.

Despite the fact that inter-partner trust, learning and partner-specific routines may reduce the need for enhancing incomplete contracts, they can simultaneously decrease renegotiation costs and risks and facilitate the enhancement of incomplete contracts. Given that prior ties set the ground for calculative trust, partners should have more to lose than to gain in adopting opportunistic behaviors or devious maneuvers during the renegotiation process itself. When contracts are incomplete, parties intentionally or unintentionally leave certain issues open for future negotiation but agreeing in the future is subject to haggling and ex post opportunism (Masten, 2002). As collaborative projects progress, parties may disagree about how to allocate risk and rewards in the light of new information. As a result of their history of prior collaborations and the shadow of the future, partners should believe that the costs and benefits of complying outweigh those associated with self-interested and opportunistic actions. They can then better form ex ante expectations about the outcomes of renegotiation. Prior collaborations streamline the renegotiation process in a smooth and collaborative manner (Bradach and Eccles, 1989). Besides calculative trust, a history of prior ties contributes to the confidence in the partner's integrity. Previous research has suggested that strengthening formal mechanisms may signal suspicion and a lack of belief in partners' goodwill or competence (Ghoshal and Moran, 1996; Malhotra and Murnighan, 2002). Non-calculative trust gained from repeated ties may weaken such beliefs and ease the renegotiation process. When calculative and non-calculative trust is enhanced, the action of expanding contracts ex post is less likely to be perceived as a signal of suspicion. The need to expand the formal contract can be explained by partners' interest to use the contract as a planning and tracking device (Llewellyn, 1931) for their future deals (Das and Teng, 1998; Poppo and Zenger, 2002). As collaboration problems are resolved over the course of the focal JV, solutions can gradually be incorporated into the contract for fruitful future collaborations. The adjusted contract codifies the partners' knowledge about efficient ways to collaborate and can serve as repository of knowledge (Mayer and Argyres, 2004). Partners indeed learn how to handle the transaction per se and the associated sources of inefficiencies over the lifespan of the JV. Also, contractual safeguard adjustments can augment calculative trust and reduce the magnitude of ex post bargaining.

Simultaneously, JV partners are able to develop routines and capabilities for governance changes and renegotiation when they have had prior ties (Argyres and Mayer, 2007). They can rely on mutually accepted heuristic guidelines of how the renegotiation process should be conducted. Collaborative routines and capabilities gained from prior inter-partner experiences contribute to smoother renegotiation (Zaheer et al., 1998). There is less ambiguity in the patterns of interaction, higher reliability for the renegotiation outcomes, and greater comfort in interaction itself (Cohen and Bacdayan, 1994; Hoang and Rothaermel, 2005). In summary, these arguments suggest that prior ties might facilitate, rather than substitute, the renegotiation of incomplete contracts as they reduce the costs and risks implied by the renegotiation process. Relational governance resulting from prior ties allows firms to achieve (cost efficient) expansion of formal contracts, which can then be used as repository of information for the ongoing as well as future collaborations. Thus, we provide the following competing Hypothesis:

Hypothesis 1b. Prior ties between partners strengthen the association between JV contractual incompleteness and the ex post expansion of contractual safeguards.

\footnotetext{
${ }^{2}$ While the existence of prior ties can be a reason for (intentional) contract incompleteness, incompleteness arises also because of other reasons such as the difficulty of anticipating all the needs of the collaboration at the outset of exchange or the excessive initial contracting costs (Williamson, 1991). Prior ties can have an influence on those other reasons; hence influencing not only the initial contract design but also contractual decisions made ex post.
} 


\section{$J V$ boards of directors and contractual renegotiation}

As argued above, besides relational governance gained from prior ties, another critical type of governance is at play during the execution of the JVs. The board of directors may greatly influence contract application and affect decisions to renegotiate the contract as well. Its ability to do so depends on the extent to which board members are actually involved in undertaking monitoring and coordination functions over the lifespan of the JV (Klijn et al., 2013; Reuer et al., 2014). These two functions are closely intertwined in practice (e.g., Adams et al., 2010). By executing their control function, boards are better able to coordinate activities and vice versa. $\mathrm{JV}$ boards of directors can lower potential inefficiencies from incomplete contracts by first acting as a monitoring and control apparatus. Because the JV itself is a separate entity, its board offers a seat of authority and acts as a formal governance mechanism that can detect opportunism and enable partners to exert their rights (e.g., Jap and Anderson, 2003). Even in the absence of contractual sanctions for non-compliance, an involved board is still able to guard against harmful actions by JV partners (Raheja, 2005; Zahra and Pearce, 1989) and to exercise its veto power (Hewitt, 2005). This is enabled by its ability to audit, verify claims and actions of JV partners, and monitor JV performance over time (Balakrishnan and Koza, 1993). The board has the function of ratifying and monitoring senior management's decisions and behaviors on behalf of the parent firms (e.g., Janger, 1980; Kumar and Seth, 1998; Pisano, 1989). It serves as an administrative structure that is capable of making the damages from a breach of trust exceed the gains from opportunistic behavior (Ring and Van de Ven, 1992). Boards also can make the rewards for being trustworthy more attractive than the gains from self-seeking behaviors (Lewicki and Bunker, 1996). The active control function by the board can therefore help to detect and address problems rapidly; hence reducing the losses incurred and moral hazards (e.g., Balakrishnan and Koza, 1993; Pisano, 1989). If perceptions of inequity exist for too long, a partner is likely to reduce its commitment to the JV (White and Lui, 2005). As a result, rewards and sanctions implemented by an involved board may incentivize the exchange and deter opportunistic behaviors even in the presence of contractual gaps.

Besides the control function, an involved board can support inter-partner coordination. It is expected to reconcile partners' needs and interests (Kumar and Seth, 1998) and to help JV partners gain exclusive insights into each other (Dyer and Singh, 1998; Harrison et al., 2001). The exchange of high-quality information about short-term and long-term business plans is a central means for adjusting existing exchanges to comply with short-term and long-term business goals (Palay, 1984). The JV board offers such a platform where partners can interact and meet. While the JV board constitutes an important control mechanism, the fact that it comprises directors from the partnering firms also makes it an effective platform to strengthen social relationships between those firms. By actively participating in strategic planning and the approval of JV budgets and short-term plans (Kumar and Seth, 1998; Pisano, 1989), the board can help JV partners identify to each other and learn about each other's motives and interests (Ravasi and Zattoni, 2006). Those activities foster stability in alliances and set the ground for stronger beliefs about each partner's goodwill, honesty, and good-faith efforts. They should therefore mitigate the negative consequences of omitted coordination-related provisions.

Overall, the more involved the board is in monitoring and coordinating the focal JV, the greater its ability will be to actively learn about the JV specificities and requirements and to deliberately transform experiences gained through the ongoing collaboration into collaborative capabilities (Felin et al., 2012; Heimeriks and Duysters, 2007). Such capabilities ease the development of partnerspecific routines related to operations, management systems or procedures (Pisano, 1989), and the adaptation of those routines if needed. JV boards are therefore well positioned to mitigate potential inefficiencies stemming from incomplete contracts and to act as a collective memory. This set of arguments supports the idea forwarded by prior research that the board of directors can address gaps in JV contracts and substitute critical but missing contractual provisions (Oxley, 1997; Pisano, 1989; Reuer et al., 2014). This leads to our first Hypothesis on the impact of JV boards in contractual renegotiation:

Hypothesis 2a. Involvement by the JV board of directors weakens the association between JV contractual incompleteness and the ex post expansion of contractual safeguards.

By adopting a similar logic that was to explain the effect of prior ties, JV board involvement potentially facilitates contractual changes as well, because it can reduce the costs and risks of renegotiation. Due to the complexity of JV arrangements, it is difficult to specify ex ante partners' respective rights and duties as well as their legitimate claims on surplus created (Borys and Jemison, 1989). Partners may therefore negotiate relatively incomplete contracts and anticipate their later renegotiation with the support of an involved board that is able to gain more insights about the peculiarities of the JV context and the interests of the parties over time. The administrative capabilities and experience of the JV directors can be used for identifying when such changes are warranted and how to go about adapting the JV arrangement. The board of directors can serve as a mediation and negotiation forum to align JV partners' interests and goals and to build consensus (Ravasi and Zattoni, 2006). Directors are responsible for handling blockages, tensions and inefficiencies caused by coordination failures or excessive vulnerabilities. Expanding incomplete JV contracts ex post can be explained by the board's inclination for legal formalization of ex post adjustments. Reaching a unified stance within JV boards might be more complex than in unitary organizations as board members, selected by the parent firms, tend to defend the interests of their parent firm (Hewitt, 2005; Janger, 1980; Reuer and Klijn, 2018). Given the diversity of partners' goals and the potential conflicting nature of their operation modes (Schaan and Beamish, 1988; Shenkar and Zeira, 1992), JV boards may see contractual renegotiation as a means of formally and sequentially readjusting parent firms' rights and obligations (Björkman, 1995). Such formalization eases third party enforcement in the event of dispute escalation and persisting conflicts (Lyons and Mehta, 1997). Contracts correspond to "a norm of ultimate appeal when the relations cease in fact to work" (Llewellyn, 1931: 737). They also serve as framework for guiding the course of cooperation (Argyres and Mayer, 2007). The contractual adjustments can be made with the precise aim of preventing similar disputes from arising in the ongoing JV, or of providing a contractual basis for resolving them. 
Boards are expected to represent, consider, and balance respective strategic objectives in an amicable way and in good faith (Hewitt, 2005). Direct contacts between parent and JV executives during board meetings play a critical role here (Killing, 1983). Through these contacts, an involved board accumulates experience and develops capabilities and routines for reaching consensus in a collaborative spirit (Kale et al., 2000). It also reduces possible asymmetrical information by providing enhanced opportunities for gathering information about partners' assets and for learning about each other (Balakrishnan and Koza, 1993). This should eventually reduce the risks and costs associated with contractual renegotiation. Partners can better anticipate the outcomes of the renegotiation process, as well as the partner's reactions and behaviors. As a result, involvement by the JV board of directors can also facilitate and encourage, rather than substitute, contractual renegotiation to enhance incomplete contracts. Thus, we provide the following competing Hypothesis:

Hypothesis 2b. Involvement by the JV board of directors strengthens the association between JV contractual incompleteness and the ex post expansion of contractual safeguards.

\section{Methods}

\section{Sample and data}

To test our set of competing hypotheses, we use data collected through a survey on JV governance and management. We relied upon two data sources to identify firms engaged in JVs as well as potential respondents: the Thomson Reuters Security Data Corporation (SDC) database and the alumni database of a European business school. We first compiled a list of Dutch firms with the names of responsible managers engaged in JVs from the SDC database and matched these names with the alumni database. We also contacted alumni from the same European business school, who were working in those listed firms and had at least ten years of work experience. We inquired whether they could pass the survey on to an informant or refer us to the executive who was directly involved in these deals, when they were not in position to respond to the survey themselves. Our focus on Dutch firms facilitated the administration of the survey as well as the follow-up process because coauthors lived in the Netherlands. In addition, when no alumni were identifiable in the list of Dutch managers, cold calls were made to the executives who were recorded in the SDC database.

In order to ensure face validity of our survey instrument, we pre-tested the questionnaire with three senior executives involved in JV negotiations or serving on one or more JV boards, as well as with five academics familiar with alliance governance. We distributed a total of 664 surveys and obtained 175 responses (i.e., 26.4\%) from 133 different parent organizations. These firms originated from 49 different countries. In completing the questionnaire, respondents were asked to select the JV with which they were most familiar. A total of $59 \mathrm{JVs}$ were domestic deals. As our focus relates to the occurrence and extent of contractual renegotiation, we excluded 20 JVs that were initially negotiated in the year of the survey administration or the year before. We discuss in the robustness section the results obtained when retaining those JVs. After accounting for responses with missing data, our final sample consists of $145 \mathrm{JVs}$. The relatively high response rate results from the efforts made to identify the target population, the follow-up messages, the motivation of alumni to participate in the project and get access to our findings, as well as the assurances of confidentiality offered to respondents (Dillman, 2007).

In line with prior research, we relied on key informants when collecting data (e.g., Krishnan et al., 2006). The use of key informants is appropriate in this context given the absence of the needed information in secondary data sources and the confidential nature of contractual information in general (Carson, 2007). In assessing the competence of our respondents, we asked whether they were members on the board, responsible for evaluating the JV, or directly involved in JV negotiations (Kumar et al., 1993). As an indication of the overall competency of respondents, $95.0 \%$ of them had managed or evaluated the JV, or took directly part in their negotiations.

We performed several tests in order to ascertain the quality of our data. First, comparative tests of independence reveal no differences in the temporal or sectoral distributions of early and late respondents' JVs (i.e., $t=0.41$, n.s. and $\chi^{2}=7.52$, n.s., respectively) (Armstrong and Overton, 1977). Second, while our research design utilizes cross-sectional econometric techniques, we paid particular attention to the wording of our questions in a way that respects the temporality of the initial contracting and renegotiation phases suggested in our model. Third, we used several procedural remedies to address potential common method bias, namely: a) protection of respondents' identities to avoid socially desirable responses; b) reliance on quasi-objective theoretical variables that do not relate to attitudes, behaviors or perceptions; c) distinct wording of the questions used for the dependent and independent variables; and d) inclusion of questions related to the dependent and independent variables in different sections of the questionnaire (Podsakoff et al., 2003). Finally, although the variables included in our analyses are mostly objective variables, which tend to be less susceptible to common method bias than perceptional variables (Golden, 1992), three tests were undertaken to identify whether a significant amount of common variance exists in the data. We performed Harman's (1967) one-factor test. Results of the exploratory factor analysis reveal eight factors with an eigenvalue greater than one. Only $13.0 \%$ of the variance in the variables used in the study is explained by the first factor. Also, we used the general factor covariate technique, which consists in adding the first unrotated factor as a control in the regression models (Podsakoff et al., 2003). Our findings remain similar despite this addition. As a final test, we used a latent variable measurement model (by adopting structural equation modeling) in which we let the perceptional items load on one common factor and compare this with a model in which the items load only on their respective factors (Lindell and Whitney, 2001; Malhotra et al., 2006). We applied this model with the items relating to board involvement and uncertainty as those items tend to be of a more perceptional nature than the other survey items. Fit of the common factor model is significantly worse $\left(\Delta \mathrm{df}=1 ; \Delta \chi^{2}=76.21, p<0.01\right)$, and similarly standardized factor loadings of the common factor model are 
substantially lower (Satorra and Bentler, 2001). ${ }^{3}$ These tests alleviate the concern that the perceptional measures captured in the survey are subject to common method bias.

\section{Model specification and measures}

Testing our hypotheses requires a two-stage model. From a first-stage equation, we are able to appraise initial contractual incompleteness. The second-stage equation estimates the impact of incompleteness on the propensity to enhance contractual safeguards ex post, and the moderating effects of prior ties and board involvement. In our post-hoc analyses described below, we address potential endogeneity concerns as well as show the robustness of our results. Our models account for the ordinal nature of our dependent variables in both stage equations. As we rely on the list of eight contractual safeguards developed by Parkhe (1993), the dependent variable initial contractual safeguards used in the first-stage equation ranges from zero to eight depending on the number of those provisions included at JV formation. To compute the dependent variable contract expansion used in the second-stage equation, we asked respondents to select which provisions out of those proposed by Parkhe (1993) had been added or strengthened through renegotiation. In both stages, ordered probit regression is adopted. Unlike ordinary least square (OLS) estimation, ordered probit accommodates unequal differences between ordinal categories in the dependent variable (Greene, 2007; McKelvey and Zavoina, 1975). Given that in some cases we obtained multiple responses per firm, our models account for possible interdependencies between JVs negotiated by a same firm by clustering firm observations and computing robust standard errors (Greene, 2007). Appendix I provides an overview of all variables and their measurement.

\section{Contract expansion}

Parkhe (1993)‘s measure has been widely adopted by scholars investigating contractual governance (e.g., Ariño et al., 2008; Deeds and Hill, 1999; Lumineau and Malhotra, 2011; Reuer and Ariño, 2002, 2007). It is based on a checklist of contractual safeguards obtained from computer-aided search of the relevant legal literature (e.g., Macneil, 1978; Narasimhan, 1989). Those safeguards are presented in Table 2a. A score is created by summing the safeguards enhanced after the formation of the JV. It takes nine discrete values going from zero if JV partners did not add or strengthen any of these safeguards to eight if all of them were either added or strengthened.

\section{Contractual incompleteness}

Following prior research, we compute our measure of contractual incompleteness through a first-stage contractual choice equation (Silverman et al., 1997). In this equation, we include a broad set of exchange attributes. We obtain the raw regression residuals from this first-stage equation (Bercovitz et al., 2006; Garen, 1984), which capture the difference between the theorypredicted and actual use of safeguards. The use of residuals matches the continuous nature of contractual incompleteness, with greater negative residuals indicating greater incompleteness of the contract relative to the exchange attributes that indicate the need for safeguards. Our variable, contractual incompleteness, corresponds to the absolute value of the residuals when the residuals are negative and to zero when the residuals are positive. In computing the residuals, we account for the ordinal nature of our dependent variable in the first-stage equation (i.e., initial contractual safeguards). ${ }^{4}$

In this first-stage equation, we first control for the environmental uncertainty in the host country (Anderson and Dekker, 2005). Respondents were asked to indicate the degree to which at the moment of forming the JV the following five external factors were predictable using a five-point Likert scale: (1) government policies and regulations, (2) customer demand, (3) supply of raw materials and equipment, (4) competitive climate, and (5) technological trends (Kumar and Seth, 1998). We reverse code the scores and weight these items based on respondents' allocation of 100 points among these five factors regarding their importance in determining the ultimate success of the JV.

We also control for small numbers bargaining that can expose JV partners to contractual hazards and hold-up (Williamson, 1975). The variable small numbers is indicated by the number of other firms that would be interested in forming a collaborative venture with the firm in case the JV would be discontinued (reverse coded). Third, we capture with a dummy variable whether or not the JV is a greenfield venture. We expect greenfield $J V$ contracts to be more elaborate as there is no existing and available structure to rely on (Meyer and Estrin, 2001). Associated contracts must encompass various dimensions implied by the launch of a new venture specific to JV partners' respective requirements.

Fourth, we use a dummy variable to indicate the existence of multiple partners in the JV (i.e., multi-partner JV). The transactional complexity caused by multiple parties further constrains the possibility of negotiating "complete" contracts (Gong et al., 2007). Fifth, as international JVs typically encounter greater difficulties in coordinating and enforcing agreements as compared to domestic JVs (Oxley, 1997), we include the dummy variable cross-border JV. To address potential differences in contractual design and contracting practices across industries, we also include in the models sector fixed-effects.

Finally, four variables are incorporated for guaranteeing the uniqueness of the first-stage equation and mitigating potential endogeneity issues. First, we control for the initial JV size, as indicated by the number of employees in the JV at the formation stage. A logarithmic transformation is used due to the significant positive skewness. Second, the initial JV scope indicates which of the six

\footnotetext{
${ }^{3}$ Similar results emerge when we also add the five alliance capability indicators to the common factor model and to a three-factor model $(\Delta \mathrm{df}=3$; $\Delta \chi 2=233.14, \mathrm{p}<0.01)$.

${ }^{4}$ Details about the method used to obtain those residuals are available upon request.
} 


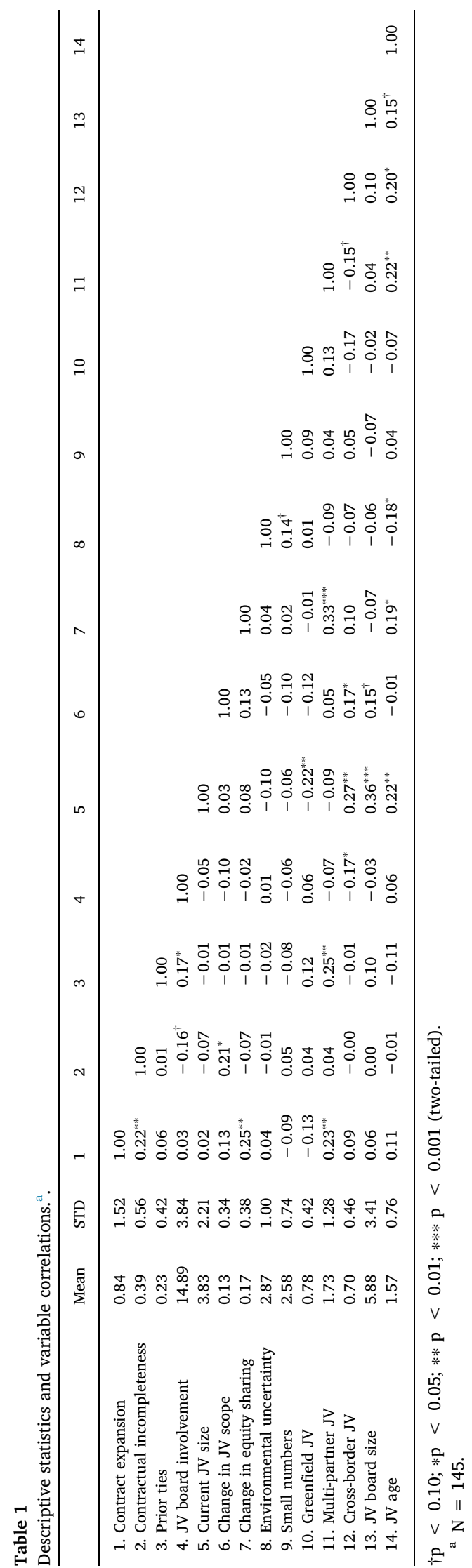


Table 2a

Percentage adoption of safeguards in the initial and enhanced contract.

No renegotiation for enhancing safeguards Renegotiation

Of which:

S1. Periodic written reports of all relevant transactions

S2. Prompt written notice of any departure from the agreement

S3. The right to examine and audit all relevant records through a firm of Certified Public Accountants

S4. Designation of certain information as proprietary and subject to confidentiality provisions

S5. Non-use of proprietary information even after termination of the agreement

S6. Termination provisions for the agreement

S7. Arbitration clauses

S8. Lawsuit provisions
$63.8 \%$

$36.2 \%$

\% likelihood for safeguard to be enhanced in contract 27.5

12.1

12.1

9.4

5.4

10.7

4.0

2.7

Table 2b

Percentage of contracts with\# of safeguards adopted ex ante and enhanced ex post.

\begin{tabular}{|c|c|c|}
\hline \# of adopted safeguards in contract & Percentages of ex ante contracts & \% likelihood for JV contract to be enhanced \\
\hline 1 & 2.7 & 0.0 \\
\hline 2 & 5.4 & 37.5 \\
\hline 3 & 8.1 & 33.4 \\
\hline 4 & 11.4 & 41.2 \\
\hline 5 & 14.8 & 59.1 \\
\hline 6 & 14.1 & 57.2 \\
\hline 7 & 16.1 & 29.2 \\
\hline 8 & 26.2 & 17.9 \\
\hline
\end{tabular}

following activities were included in the JV: basic research, new product or process development, testing and obtaining regulatory approval, manufacturing, marketing, sales, and distribution (e.g., Li et al., 2012). Third, we use a scale that reflects alliance capabilities (Heimeriks et al., 2009; Kale and Singh, 2007). Alliance capabilities should ease the drafting of contractual safeguards and favor their inclusion. Respondents were asked to rank on five-point Likert-type items their use of the five following practices: (1) directories for internal or external experts who can provide assistance on alliance management, (2) detailed processes for alliance formation and management, (3) checklists or guidelines supporting managerial decisions and actions; manuals containing tools, (4) templates or frameworks for managerial decisions and actions, and (5) updates to checklists, guidelines, and manuals that have been developed and are in use (Cronbach alpha $=0.75$ ). We control for the expected duration of the alliance at the formation phase as this shapes the shadow of the future, and so the contract drafting (Parkhe, 1993). JV definite is equal to one when partner firms engaged in a temporary JV with a fixed duration and zero otherwise.

\section{Prior ties}

We asked respondents how many prior collaborations were formed with the partner(s) before setting up the focal JV. We use a log transformation of one plus the number of prior collaborations since this variable exhibits significant positive skewness (e.g., Gulati, 1995). This count measure, which is a general proxy for relational governance, fits our research setting as it mitigates the risk of hindsight bias (Golden, 1992). We cannot make assertions that respondents would be able to provide reliable indications of e.g. how much they trusted a partner or learnt about that partner at the moment of renegotiation per se (e.g., hindsight bias). This might lead to potential for reverse causality. A count of prior ties in that sense represents a more objective measure that is less sensitive to hindsight bias (Golden, 1992). Relatedly, this measure enables to unpack the trust, norms and learning subsumed under the relational governance gained from prior collaborations (prior to the focal JV) and those subsumed under the formal governance provided by an active JV board (throughout the focal JV).

\section{Board involvement}

We adopted the four-item scale developed by Kumar and Seth (1998) that captures the extent to which the JV board was involved in a) drawing up strategic plans, b) approving budgets and plans, c) monitoring the JV, and d) coordinating JV and parent actions (Cronbach alpha $=0.84)$.

\section{Control variables}

Several control variables are introduced in the second-stage equation. Efficient and equitable contracts may be designed at the time of the establishment, but changes and contingencies occur and may necessitate renegotiating even initially "complete" contracts. For this reason, we first add variables included in the first stage that might generate ex post contingencies and directly influence the extent of renegotiation. We control for environmental uncertainty, as after JV formation, changes in the environment can trigger governance adjustments to restore initial conditions of equity and efficiency (e.g., Ariño and de la Torre, 1998). We also control for small numbers, because firms may attempt to appropriate value from partners via renegotiation when those partners have limited alternative partners (Reuer and Ariño, 2002; Williamson, 1975). 
In addition, we incorporate three control variables that relate to the complexity of the JV. In greenfield JVs, compared to acquisitive JVs, there should be a lower likelihood of renegotiation. Acquisitive JVs may require deep restructuring over time to overcome a possible lack of fit between partners (e.g., Harzing, 2002). In multi-party JVs, there is a juxtaposition of cooperation to achieve mutual goals but also a greater potential of partners pursuing self-interests (Kogut, 1988). Chances of tensions and goal incongruence increase and lead to governance adjustments (Luo and Park, 2004). Cross-border JVs are more susceptible to instability and extra coordination and enforcement difficulties (e.g., Killing, 1983). We also include in the models sector fixed-effects.

Five additional control variables serve to uniquely identify our second-stage equation. We control for the change in JV scope via a dummy variable equal to one if the JV scope was altered over the course of the JV, and to zero otherwise. We also account for changes in equity sharing during completion of the JV. This variable is equal to one if changes took place. We control for the current JV size as well as for the size of the $J V$ board (i.e., the number of directors), because a larger number of directors can make renegotiation more time-consuming. This potentially impacts costs and risks of renegotiation (Yermack, 1996). Finally, we include $J V$ age. We asked respondents for the year of the JV establishment and create three main categories: up to five years; between six and ten years; and older than ten years.

\section{Results}

Table 1 reports descriptive statistics and correlations for the variables included in the second-stage model, our model of interest. The highest correlation is 0.36 and the maximum variance inflation factor (VIF) is 2.42 for the first-stage equation and 2.23 for the second-stage equation, well below common thresholds that indicate multicollinearity problems. As far as the initial JV contract is concerned, the mean number of focal contractual safeguards observed in our sample is 5.64. The safeguard most commonly included at the formation stage relates to the termination of the agreement (81.2\%), while the least included provision refers to lawsuit provisions (49.7\%). Overall, 36.2\% of the sampled contracts were renegotiated to enhance safeguards. The most commonly enhanced safeguard concerns periodic written reports of all relevant transactions, while lawsuit provisions are enhanced least often. Tables $2 \mathrm{a}$ and $2 \mathrm{~b}$ provide an overview of the renegotiated safeguards.

As far as the results obtained for the first-stage equation are concerned, the extent of initial contractual safeguards is positively influenced by alliance capabilities $(\beta=0.08 ; p=0.00$; two-tailed), as well as by greenfield JV ( $\beta=0.37 ; p=0.09)$, JV definite $(\beta=0.39 ; p=0.09)$, and cross-border $J V(\beta=0.45 ; p=0.08)$.

Table 3 presents the results of six ordered probit regression models. The models include control variables only (I), main effects of the theorized variables (II), separate interaction effects of prior ties and board involvement with contract incompleteness (III and IV), and the full specification that includes both interaction effects (VI). In addition, model V shows the results for the full model that excludes control variables also used in the first-stage estimation of contract incompleteness and is discussed in the section on robustness tests. Findings obtained in the full model (model VI in Table 3) reveal that the likelihood that safeguards are added or enhanced through renegotiation increases with contractual incompleteness $(p=0.03)$. Concerning our set of competing hypotheses, results show that prior ties negatively moderate this effect $(p=0.00)$ (i.e., Hypothesis 1a is supported). Interestingly, the positive main effect of prior ties also becomes significant $(p=0.00)$. This finding indicates that firms with prior ties are more likely to

Table 3

Expansion of JV contracts - Ordered Probit Estimation Results. .

\begin{tabular}{|c|c|c|c|c|c|c|}
\hline \multirow[t]{2}{*}{ Sector fixed-effect } & I & II & III & IV & $\mathrm{V}$ & VI \\
\hline & Incl. & Incl. & Incl. & Incl. & Incl. & Incl. \\
\hline Current JV size & $-0.06(0.06)$ & $-0.06(0.06)$ & $-0.09(0.06)$ & $-0.07(0.06)$ & $-0.05(0.05)$ & $-0.12^{\dagger}(0.06)$ \\
\hline Change in JV scope & $0.32(0.26)$ & $0.12(0.29)$ & $0.20(0.29)$ & $0.07(0.30)$ & $0.42(0.28)$ & $0.14(0.30)$ \\
\hline Change in equity sharing & $0.40(0.25)$ & $0.58^{* *}(0.22)$ & $0.70^{* *}(0.24)$ & $0.59^{* *}(0.21)$ & $0.66^{* *}(0.25)$ & $0.74^{* *}(0.23)$ \\
\hline Environmental uncertainty & $0.09(0.09)$ & $0.08(0.09)$ & $0.11(0.10)$ & $0.09(0.09)$ & - & $0.13(0.10)$ \\
\hline Small numbers & $-0.06(0.16)$ & $-0.06(0.14)$ & $-0.13(0.14)$ & $-0.08(0.15)$ & - & $-0.18(0.15)$ \\
\hline Greenfield JV & $-0.54^{*}(0.27)$ & $-0.67^{* *}(0.26)$ & $-0.80^{* *}(0.27)$ & $-0.66^{*}(0.27)$ & - & $-0.81^{* *}(0.29)$ \\
\hline Multi-partner JV & $0.16^{\dagger}(0.09)$ & $0.10(0.10)$ & $0.09(0.11)$ & $0.09(0.10)$ & - & $0.09(0.10)$ \\
\hline Cross-border JV & $0.53^{\dagger}(0.31)$ & $0.53(0.33)$ & $0.65^{\dagger}(0.35)$ & $0.60^{\dagger}(0.34)$ & - & $0.82^{*}(0.36)$ \\
\hline JV board size & $0.03(0.03)$ & $0.02(0.03)$ & $0.04(0.04)$ & $0.03(0.03)$ & $0.04(0.03)$ & $0.05(0.03)$ \\
\hline JV age- $26-10$ years & $0.16(0.28)$ & $0.01(0.26)$ & $0.02(0.27)$ & $-0.02(0.26)$ & $0.05(0.26)$ & $-0.03(0.27)$ \\
\hline JV age- $3>10$ years & $0.05(0.29)$ & $0.17(0.30)$ & $0.21(0.30)$ & $0.24(0.31)$ & $0.32(0.26)$ & $0.35(0.31)$ \\
\hline Contractual incompleteness & - & $0.46^{*}(0.22)$ & $0.29(0.22)$ & $0.59^{*}(0.24)$ & $0.39^{\dagger}(0.22)$ & $0.48^{*}(0.22)$ \\
\hline Prior ties & - & $0.38(0.32)$ & $0.54^{* *}(0.17)$ & $0.38(0.33)$ & $0.48^{* *}(0.16)$ & $0.64^{* * *}(0.17)$ \\
\hline JV board involvement & - & $0.01(0.03)$ & $0.00(0.03)$ & $-0.09(0.11)$ & $-0.16(0.11)$ & $-0.21(0.13)$ \\
\hline $\begin{array}{l}\text { Contractual incompleteness* } \\
\text { Prior ties }\end{array}$ & - & - & $-0.77^{* *}(0.23)$ & - & $-0.64^{* *}(0.23)$ & $-0.93^{* * *}(0.25)$ \\
\hline $\begin{array}{c}\text { Contractual incompleteness* } \\
\text { JV board involvement }\end{array}$ & - & - & - & $0.31^{\dagger}(0.17)$ & $0.36^{*}(0.15)$ & $0.51^{* *}(0.18)$ \\
\hline Pseudo R2 & 0.06 & 0.09 & 0.11 & 0.09 & 0.09 & 0.13 \\
\hline Prob > Chi2 & 0.00 & 0.00 & 0.00 & 0.00 & 0.01 & 0.00 \\
\hline
\end{tabular}

$\uparrow \mathrm{p}<0.10 ; * \mathrm{p}<0.05 ; * * \mathrm{p}<0.01 ; * * * \mathrm{p}<0.001$ (two-tailed).

${ }^{\text {a }} \mathrm{N}=145$. Robust standard errors. 
renegotiate JV contracts regardless of their level of incompleteness. The propensity to renegotiate can be here explained by the ongoing learning about the focal JV transaction, its requirements and the rights and duties of the partners involved. Partners with prior interactions tend to value those opportunities to further build on the idiosyncratic and collaborative routines they developed over time, and to set the ground for future trade value (Pisano, 1989). Contracts can then be used as a repository of information and knowledge for fruitful collaborations in the future (Mayer and Argyres, 2004). Such a repository can be enriched over the course of the collaboration as JV partners learn about the focal transaction. Well-defined contracts enable future projects to benefit from experiences gained in earlier collaborations; thereby improving the performance of these later collaborations (Poppo et al., 2008). Therefore, independent from the level of contractual incompleteness, prior ties facilitate and directly foster contractual renegotiation of JV contracts. In contrast to the moderating effect of prior ties, board involvement positively moderates the propensity to enhance incomplete JV contracts ( $p=0.04$ ) (i.e., Hypothesis $2 \mathrm{~b}$ is supported).

Because of the non-linearity of ordered probit models, it is recommended to further analyze the marginal effects (Hoetker, 2007). ${ }^{5}$ A thorough examination of the marginal effects provides support for the coefficients reported in Table 3 (details are available upon request). The graphical representations below illustrate our findings. Given the skewness of the variable prior ties, we create a dummy variable equal to one when partners had prior collaboration, and to zero otherwise. This latter variable is used for obtaining Fig. 1. As indicated in the robustness section, findings remain stable when the existence of prior ties, instead of the extent of prior ties, is accounted for. Fig. 1 displays that prior ties reduce the likelihood of enhancing incomplete JV contracts. ${ }^{6}$ For obtaining Fig. 2 , we take the value of board involvement at two standard deviations above and below its mean. This latter figure shows that the enhancement of contractual safeguards is more likely when JV boards are more involved.

The results for several of the control variables are also worth noting. The full model VI in Table 3 shows, based on the ordered probit coefficients, that the enhancement of contractual safeguards relates positively and significantly to a change in equity sharing $(p=0.00)$ and occurs more commonly in cross-border alliances $(p=0.02)$. In addition, enhancement of safeguards takes place less often in greenfield JVs $(p=0.01)$ and larger JVs $(p=0.06)$.

\section{Robustness tests}

We perform several supplemental analyses in order to assess the robustness of our results. First, to address the endogeneity concern of prior ties and board involvement also influencing the initial contract and its incompleteness, we run the same set of regressions by including in the first stage the extent of prior ties as well as a measure of the scope of contractually agreed-upon responsibilities to be undertaken by the JV board of directors. ${ }^{7}$ In order to compute this latter measure, respondents were asked the extent to which board members were considered responsible for (1) selecting and overseeing the JV general manager, (2) planning for management development and succession, (3) approval of compensation and incentive programs, (4) reviewing and monitoring the implementation of strategic plans, (5) approving operating plans, capital expenditures, and budgets, (6) focusing on the integrity and clarity of financial reports, (7) advising JV management on significant issues, (8) reviewing and approving significant JV actions, (9) reviewing management's plans for business resiliency, (10) nominating directors or committee members and overseeing effective JV governance, (11) overseeing legal and ethical compliance, and (12) monitoring overall JV performance (Geringer and Hébert, 1989; Kumar and Seth, 1998) (Cronbach alpha $=0.92$ ). Including these variables in the first-stage equation enables to consider the overall contractual misfit, rather than the incompleteness vis-à-vis transaction and exchange attributes. Results obtained for the full model VI remain consistent $\left(\beta=-0.87, p=0.00\right.$ for the interaction with prior ties; $\beta=0.40, p=0.02$ for the interaction with board involvement). ${ }^{8}$

Second, we replace our ordinal dependent variable - contract expansion - by a dummy variable that equals one when the contract was enhanced ex post and zero otherwise. Probit regressions provide consistent results for the moderating effects. Third, in order to exclude JVs for which informal governance is primarily used, we drop cases where contracts did not include any of the contractual safeguards listed by Parkhe (1993) (i.e., in 1.34\% of our sample). Our findings remain consistent. Fourth, we replace the measure of prior ties with a dummy variable capturing the presence or absence of prior ties, and find the same pattern of results. Fifth, we expand the sample by including cases where JVs were formed within the year of the survey and include a dummy variable to control for those cases in the second-stage equation. Such JVs have had less opportunity for contractual renegotiation. The same inferences are obtained again. Sixth, in order to ascertain that including a same set of independent variables in both stage equations does not generate endogeneity concerns, we exclude the overlapping variables from the second-stage equation. Findings are shown in model $\mathrm{V}$ (Table 3) and do not lead to differences with our initial results.

\footnotetext{
${ }^{5}$ Marginal effects shows the effect of the extent of change in an independent variable on the change in probability of the focal outcome (i.e., of observing a specific number of contractual safeguards expanded ex post), while the other variables remain unchanged. The effect of the interaction in particular is a function of not only the coefficient for the interaction, but also the coefficients for each interacted variable and the values of all the other model variables (Huang and Shields, 2000).

${ }^{6}$ Figs. 1 and 2 are obtained from probit regressions rather than ordered probit regressions in order to ease graphical interpretation. Fig. 1 suggests that prior ties increase the likelihood of renegotiation of JV contracts initially less incomplete (i.e., binary variable). Firms with prior ties that develop relatively complete contracts for their JVs seem to be more likely to maintain this level of relatively completeness over time as conditions change.

${ }^{7}$ The joint inclusion of these variables also accounts for their possible interrelations, such as that prior ties influence contractually agreed board responsibilities.

${ }^{8}$ Findings also remain unchanged in model III, which accounts for the interaction with prior ties exclusively $(\beta=-0.77, p=0.00)$. However the interaction with board involvement becomes just insignificant once tested solely in model IV $(\beta=0.27, p=0.11)$.
} 


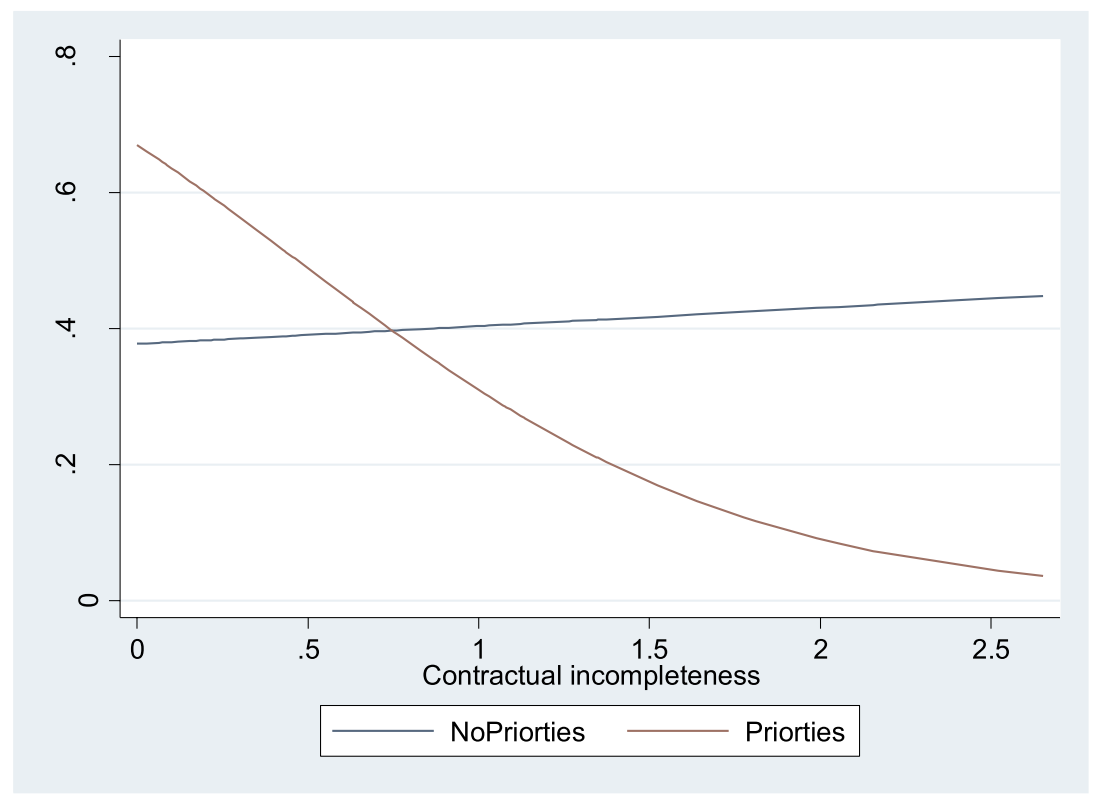

Fig. 1. Prior ties and contractual incompleteness.

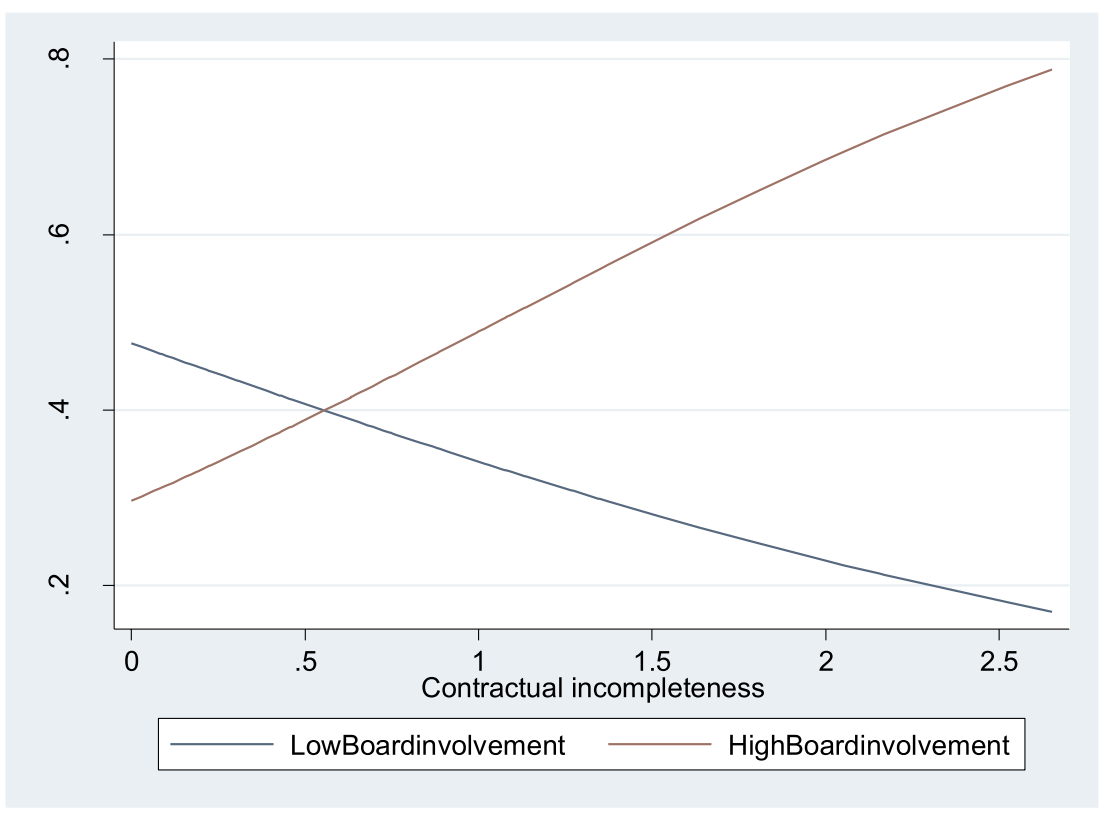

Fig. 2. JV board involvement and contractual incompleteness.

In addition, since our theory suggests that adjusting safeguards and enhancing coordination are two important motivations for contract expansion (e.g., Schepker et al., 2014), in a supplemental analysis we discriminate between those two motivations. Control provisions aim at disciplining the exchange and sanctioning deviation from contractual obligations (Macneil, 1978; Williamson, 1985). Coordination provisions offer a blueprint for facilitating smooth collaboration (Gulati et al., 2005; Macaulay, 1963; Mayer and Argyres, 2004). As such, one may expect that the mindset adopted differs when it comes to adding and strengthening control or coordination provisions over time. Also, the inefficiencies resulting from incomplete control versus coordination contractual dimensions may not have the same intensity and nature.

We explore the moderating role played by alternative governance mechanisms when the trade-off relates to control or coordination provisions. To do so, we follow the empirical studies by Reuer and Ariño (2007) and Malhotra and Lumineau (2011) and consider that the first three contractual provisions listed in Table 2a (i.e., period written reports of all relevant transactions, prompt written notice of any departure from the agreement, and the right to examine and audit all relevant records through a firm of CPA) are associated more strongly with the coordination dimension. The next five provisions are used to assess the control dimension in 
JV contracts (i.e., designation of certain information as proprietary and subject to confidentiality provisions, non-use of proprietary information even after termination of the agreement, termination provisions for the agreement, arbitration clauses, and lawsuit provisions). The two variables, coordination clauses and control clauses, are computed by summing the related provisions. In order to appraise the level of contractual incompleteness for those two dimensions, the approach adopted for the full set of provisions is replicated. From a first-stage equation, we compute two residuals and include those residuals in the second-stage equations. Independent and control variables similar to those included in our main models are added in the regressions. Findings reveal that a greater history of prior ties tends to negatively influence the extent to which both coordination and control dimensions are expanded ex post when those dimensions are initially incomplete $(\beta=-0.47 ; p=0.01$ for coordination; $\beta=-0.84$; $p=0.02$ for control). On the opposite, an involved JV board tends to positively influence expansion of both coordination and control dimensions when those dimensions are initially incomplete $(\beta=0.36 ; p=0.09$ for coordination; $\beta=0.45 ; p=0.02$ for control). These results suggest that the moderating effect played by alternative relational and formal governance mechanisms does not differ between the control or coordination dimensions in JV contracts. One reason explaining these findings might be that before sitting around the renegotiation table, JV partners cannot be certain a priori whether only coordination versus only control issues will be raised eventually during the renegotiation process. Renegotiation indeed entails uncertainty concerning its outcomes. Firms may be tempted to take advantage of this renegotiation opportunity and of the possible vulnerabilities of the counterparts to bargain opportunistically (Hart and Moore, 1988; Tirole, 1986). This remains true even if, at first, partners engaged in renegotiation for adjusting coordination provisions.

\section{Discussion}

\section{Contributions and implications}

In this study, we examine the influence of alternative relational and formal governance mechanisms - prior ties and JV board involvement - on the extent to which incomplete JV contracts are enhanced over time. Despite the potential governance benefits implied by renegotiating incomplete JV contracts, partner firms do not necessarily engage in such renegotiation in general. On the basis of survey data on JV governance and dynamics, we find that contractual incompleteness is less likely to lead to ex post contractual adjustment when partners share prior collaborations. This finding suggests that when partners engaged in an incomplete contractual arrangement, the relational governance derived from prior ties substitutes for the need to enhance this arrangement. This implies that inefficiencies caused by contractual gaps remain limited when the JV is embedded in a collaborative context between partners. We also find that JV boards highly involved in the JV execution foster the ex post enhancement of incomplete contracts. Overall, our results emphasize the need to consider the influence of alternative governance developed prior to or throughout the focal JV for understanding post-contractual dynamics. They also provide practitioners with a better understanding of conditions leading to renegotiation of incomplete $\mathrm{JV}$ contracts.

The systematic framework that we propose for investigating decisions to renegotiate incomplete contracts enables us to engage, first, with the debate concerning the usefulness of contractual governance. Although some scholars have downplayed the role of contracts in alliances (e.g., Ghoshal and Moran, 1996; Larson, 1992; Macaulay, 1963; Uzzi, 1997), our findings reaffirm the key governance role played by contracts during the execution of JV collaborations. They show at first that greater contractual incompleteness is associated with a higher likelihood of ex post enhancement of JV contracts. In line with TCE logic, this finding suggests that misaligned contracts pave the way for opportunistic behaviors and coordination failures (e.g., Anderson and Dekker, 2005). Renegotiation enables exchange partners to "repair" the overall relationship and to readjust contractual structures (Ariño et al., 2008; Reuer and Ariño, 2002). Findings also suggest that, besides being driven by the inefficiencies caused by contractual gaps, contractual renegotiation may be driven by the opportunity it affords to use contracts as a repository of information (Mayer and Argyres, 2004). This latter effect is observed independent from contractual gaps. Such insights derived from our systematic and empirical framework enable us to enrich the limited research on the trade-offs at the origin of contract renegotiation. In particular, we use this framework to appraise whether alternative relational and formal governance instruments substitute or facilitate the renegotiation of incomplete JV contracts.

A second rich debate related to our study concerns the nature of the relationship between relational and contractual governance (e.g., Hoetker and Mellewigt, 2009; Poppo and Zenger, 2002). Prior findings obtained from the ex ante contracting phase do not enable a determination whether trust- and learning-generating conditions and operational routines developed through earlier collaborations fully overcome contractual gaps and reduce the usefulness of contractual governance, or whether those same conditions and routines provide partners with an appropriate setting for enhancing their contracts ex post once difficulties related to farsightedness lessen. In other words, contractual governance and prior ties may substitute each other in explaining the occurrence of renegotiation, while they could positively be related at the negotiation phase, or vice-versa. By adopting an ex post perspective, we are able to provide new insights to this important literature and to further illuminate the complex role of prior ties. Although the recent meta-analysis of Cao and Lumineau (2015) tends to support mostly the complementarity between relational and contractual governance at the ex ante phase, our study supports both a substitution and complementary effect during the JV execution. We first argue and show that prior ties tend to reduce the need to renegotiate incomplete JV contracts. Our study therefore reaffirms the role of a "self-enforcing safeguard" played by trust and familiarity and the informal operational support offered by inter-partner routines, learning and norms (e.g., Dyer and Singh, 1998; Gulati, 1995). Prior ties can help partners mitigate the inefficiencies caused by contractual incompleteness. Yet we also observe that prior ties increase the propensity to renegotiate JV contracts independent of their level of initial incompleteness. The drivers for renegotiation in this specific setting appear to be not the occurrence of inefficiencies but rather the opportunities that renegotiation offers to solidify future collaboration. Such latter finding tends to support 
the idea widely conveyed in prior empirical research according to which formal contracting is not fully substituted by relational governance (e.g., Poppo and Zenger, 2002). Contracts then tend to be also used as repositories of learning for future collaborations (Mayer and Argyres, 2004). As partners learn about the focal JV requirements and specificities over time, they might be inclined to adjust the contract accordingly since their prior collaborations facilitate the renegotiation process. Therefore, we contend that the debate on relational and contractual governance interplay could more rigorously adopt a dynamic perspective like ours in future research. Our study shows that focusing on the contractual negotiation phase alone does not enable to fully grasp the nature of interplay between alternative governance structures in alliances.

A third nascent debate emphasized by our study concerns the nature of the relationship between JV board governance and contractual governance. Our study joins the disparate streams of research on corporate governance and alliance governance by unveiling the role played by boards in the context of JVs and contractual renegotiation in particular. This latter context is characterized by a mixture of competitive and cooperative interests (Dussauge et al., 2004). Pisano (1989) and Williamson (1991) advocate a gap-filling role played by the board during JV implementation and suggest a substitutive relation. It is not clear, however, whether an involved JV board of directors fills in these gaps or whether it facilitates contractual adaptations owing to the monitoring or coordination functions that it performs. Our study advances understanding regarding this question as it suggests that involved JV boards can ease and encourage the renegotiation process when inefficiencies caused by contractual incompleteness surface. This might be explained by the primary negotiation platform they offer for discussing and resolving inter-partner conflicting interests and blockages (Geringer and Hébert, 1989; Ravasi and Zattoni, 2006). Also, formal contracting is based on the idea that the agreed terms are verifiable and allow a third-party authority to oblige the parties to comply with them in case of non-compliance (Klein, 1980). JV directors likely will value this option in case they have not been able to handle conflicts internally and must rely on arbitration or litigation. The experiences acquired over the lifespan of the focal JV might enable directors to deal with the complexity inherent to JV arrangements and to better specify the respective rights and duties through renegotiation. As inefficiencies surface, formal mechanisms via the JV board tend to foster further development of formal mechanisms via contractual adjustment (Ariño and de la Torre, 1998; Killing, 1983). It remains for future research to study whether such dynamics infuse order into agreements and in fact lead to enhanced performance.

Finally, our study contributes to the literature on learning and experience in alliances. This literature has focused on how firms learn to collaborate in general (Child, 2001), but also on how firms learn incrementally to design contracts as they experience contingencies and hazards in former alliances (e.g., Mayer and Argyres, 2004). Learning to contract corresponds to one kind of learning in alliances, which is highly related to the learning to collaborate. The accumulation of experience about alliances in general can indeed influence the initial design of alliance contracts as it sensitizes managers to potential hazards and coordination difficulties about which they were previously unaware, enabling them to better foresee safeguards and contingencies in the future contracts (Cyert and March 1963). While prior research has contended and shown that the structures of successive contracts change over time as partners gain experience with alliances, our study focuses on experience during the focal exchange as a board is involved and potentially renegotiates the focal contract. Our study therefore highlights a type of learning, which accumulates over the lifespan of the JV itself. It concerns especially the learning about the transaction per se (Kim, 1997; Solís-Rodríguez and González-Diaz, 2018). When disagreements and problems arise in the context of a JV, adjustments can be made not only in contracts negotiated for subsequent projects but also in contracts renegotiated for the ongoing project. As partners gain experience over the lifespan of their JV, they can use renegotiation as a means to "repair" inefficiencies or as a means to "prevent" those inefficiencies and to promote future collaborations.

\section{Implications for practice}

Our study brings forward several implications for practice. The vast literature on the governance interplay in alliances draws contradictory conclusions (see Cao and Lumineau, 2015 for a recent review). Practitioners can hardly rely on this wide yet inconclusive literature when making decisions about JV contract renegotiation. Our study reveals the critical role of the broader governance context. Especially in settings where initial contracting costs are expected to be high (e.g., due to a lack of knowledge and unresolved uncertainties), firms may intentionally keep contracts incomplete on issues that they anticipate to have more understanding of at a later stage, and thus negotiate more efficiently and effectively (Crocker and Reynolds, 1993). In this process, the influence of other governance elements needs to be accounted for, as we have demonstrated.

Our study emphasizes the importance of considering different governance instruments in conjunction and how they can influence each other over time. Investing in relational governance can have a longer term impact on formal contracting than only during initial governance design, and could allow firms to also economize on subsequent contract adaptation costs. Similarly, decisions about board involvement in the JV may not only affect the direct impact of this governance mechanism on JV effectiveness, but also the extent to which partners can fruitfully renegotiate formal arrangements over time. While complex JVs will always maintain some inherent uncertainties, the longer-term effects of these governance mechanisms may already be anticipated at the time of formation and thus be taken into account in contracting decisions.

\section{Open questions and future research}

Our study helps surface a set of open questions, which serve as suggestions for future research. First, there is a need to further explore how experiences gained from prior alliances and collaboration capabilities in general - not partner-specific - drive the renegotiation of incomplete contracts. As firms learn and acquire experience in former collaborations, they not only learn to better identify the relevant features of transactions but are also able to find the best solutions for them (Argyres et al., 2007). Learning therefore enables to achieve (cost efficient) development of formal contracts (Argyres et al., 2007; Mayer and Argyres, 2004; Poppo 
and Zenger, 2002; Ryall and Sampson, 2009; Vanneste and Puranam, 2010). Besides facilitating the contracting and renegotiation process, the accumulation of collaborative experience can also mitigate inefficiencies resulting from an incomplete contract by facilitating adaptations to disturbances or by safeguarding vulnerable assets in informal ways. Our framework therefore needs to account for learning and experience gained from prior alliances more closely to provide a complete picture of the factors driving the renegotiation of incomplete contracts.

Second, research might also benefit from investigating how experiences gained over the course of the JV are turned into alliance capabilities. As argued by Lenox and King (2004) and Heimeriks and Duysters (2007), firms can differently leverage their experience for developing alliance capabilities. Prior ties and the involvement of the JV board might play key roles in turning experiences into capabilities. Relational governance tends to correspond to a "passive" more than "active" mechanism when it comes to turning experiences into collaboration capabilities. As far as the JV board is concerned, it can actively leverage the experiences gained over the course of the collaboration (Heimeriks and Duysters, 2007) and turn these into capabilities for reducing inefficiencies or facilitating renegotiation. A highly involved board can function as learning mechanism that internalizes collaborative experiences as a means to learn lessons for the future (Simonin, 1997). It would be interesting to uncover how differences in such sources of capabilities explain the propensity to renegotiate and other collaboration outcomes. Research in these directions could also provide novel insights on alliance capability development in general.

Third, our data do not enable us to distinguish situations where incomplete contracts result from unintentional mistakes (Anderson et al., 2017; Masten, 1993) or from a deliberate account of the trade-off between negotiation costs and expected inefficiencies caused by less exhaustive arrangements (Crocker and Reynolds, 1993; Williamson, 1985). It is still early in this line of research to attempt to state a definite set of conditions, but one might suspect that when partners share a history of prior collaborations, any contractual incompleteness remaining in the initial contract should be more deliberate since experiences and learning gained prior to the collaboration contribute to contract design capabilities (Kale et al., 2000; Simonin, 1997). The extent to which boards are involved or not, however, is not expected to influence the contract design capabilities at the outset of the JV since the board's actions take place ex post. The individual contract design capabilities of the board's members themselves and their prior experience should, however, matter. Individual experiences and knowledge ultimately shape the organizational learning process which impacts capability development (Felin et al., 2012; Helleloid and Simonin, 1994). It would be interesting for future research to examine whether the alliance capabilities of the directors forming the board mitigate renegotiation either due to their ability to negotiate more complete JV contracts or due to their ability to temper inefficiencies in the presence of contractual incompleteness.

Fourth, our study did not allow us to identify when contracts were altered. We therefore encourage scholars to inquire respondents about the date of the contractual renegotiation, which would allow application of survival-analysis techniques (Melnyk et al., 1995). Such techniques have been used in studies of JV stability (e.g., Dhanaraj and Beamish, 2004; Hennart et al., 1998) and could also be fruitful in the context of contractual renegotiation. In addition, while the focus of our study is on the readjustment of JV contracts, it would also be valuable to study how adjustment of the JV board's involvement takes place over time and with what consequences. For instance, JV boards of directors can differ in terms of their level and type of involvement (e.g., Kumar and Seth, 1998; Reuer et al., 2014), and the composition and structure of boards can also change during JV implementation.

Finally, instead of using a count of prior ties to measure relational governance, we encourage future research that accounts for the multidimensional nature of relational governance and distinguishes the effect of trust, learning and routines developed at different points of time (i.e., negotiation phase, prior to the renegotiation phase, and after the renegotiation phase). Recent literature asks for relying on specific measures and disaggregated analysis for each underlying concept associated with relational governance (e.g., Gulati and Sytch, 2008; Lioukas and Reuer, 2015; Mellewigt et al., 2017). Scholars can explore whether the discrepancies of results on governance interplays taking place ex ante and ex post are explained by the distinct influences of those concepts of trust, learning and routines. We also stress the importance of distinguishing the trust, routine and learning effects stemming from prior ties from those effects resulting from the active and deliberate intervention of the board of directors.

\section{Acknowledgment}

We sincerely thank the handling editor Koen Heimeriks and the two anonymous reviewers for their thorough and constructive suggestions. The authors gratefully acknowledge comments on earlier versions of the paper from Devi Gnyawali, Stéphane Saussier, Brian Tjemkes and Florian Zapkau, and from participants at seminars at Louvain School of Management and Vrije Universiteit Amsterdam and the 2017 Society for Institutional \& Organizational Economics Conference and the 2018 European Academy of Management Conference. Any errors are fully our own.

\section{Appendix I. Variables and their measurements} arbitration clauses; and h) lawsuit provisions. 
Board involvement Average of the four items using a five-point Likert-type scale (1 = "to a little extent"; 5 = "to a large extent") about the extent to which the JV board was involved in (1) drawing up strategic plans, (2) approving budgets and plans, (3) monitoring the JV, and (4) coordinating JV and parent actions.

Current JV size Log of the number of employees in the JV at the moment of responding

Change in JV scope One if the JV scope was altered over the course of the JV and zero otherwise

Change in equity shar- One if changes in equity sharing took place and zero otherwise

ing

Environmental uncertainty

Small numbers Greenfield JV Multi-partner JV Cross-border JV Initial JV size Initial JV scope

Alliance capabilities

JV definite Size JV board JV age JV sector
Weighted score of responses to five items using a five-point Likert-type scale ( 1 = "Not at all predictable"; 5 = "Accurately predictable"): (1) Government policies and regulations, (2) customer demand, (3) supply of raw materials and equipment, (4) competitive climate, and (5) technological trends.

The items are weighted based on respondents' allocation of 100 points among these factors regarding their importance in determining the ultimate success of the JV (i.e., $w_{i}, i=1$ to 5 ). The measure is calculated as follows:

Environmental uncertainty $=\frac{1}{100} \sum_{i=1}^{5} w_{i} e_{i}$

Reverse-coded score of the number of potential alternative partners

One for greenfield $J V$, zero otherwise

Log of the number of JV partners involved

Zero for domestic alliances, one otherwise

Log of the number of employees in the JV at the formation stage

Sum of the number of activities that the JV involved regarding (1) basic research, (2) new product or process development, (3) testing and obtaining regulatory approval, (4) manufacturing, (5) marketing, sales, and (6) distribution

Average score of responses to five items on the parent firms' use of the following practices ( 1 = "; 5 = "): (1) directories for internal or external experts who can provide assistance on alliance management, (2) detailed processes for alliance formation and management, (3) checklists or guidelines supporting managerial decisions and actions; manuals containing tools, (4) templates or frameworks for managerial decisions and actions, and (5) updates to checklists, guidelines, and manuals that have been developed and are in use. One when partner firms engage in a temporary JV, zero otherwise Number of directors in the JV board

Categorical measure based on the year of JV foundation ( $1=$ to five years; 2 = between six and ten years; $3=$ older than ten years) Fixed effect for the sectors following Reuer and Tong's (2006) SIC classification.

\section{References}

Adams, R.B., Hermalin, B.E., Weisbach, M.S., 2010. The role of boards of directors in corporate governance: a conceptual framework and survey. J. Econ. Lit. 48 58-1. Anderson, S.W., Dekker, H.C., 2005. Management control for market transactions: the relation between transaction characteristics, incomplete contract design and subsequent performance. Manag. Sci. 51 (12), 1734-1752.

Anderson, S.W., Dekker, H.C., Van den Abbeele, A., 2017. Costly Control: an examination of the trade-off between control investments and residual risk in interfirm transactions. Manag. Sci. 63 (7), 2163-2180.

Argyres, N., Mayer, K.J., 2007. Contract design as a firm capability: an integration of learning and transaction cost perspectives. Acad. Manag. Rev. 32 (4), 1060-1077.

Argyres, N.S., Bercovitz, J., Mayer, K.J., 2007. Complementarity and evolution of contractual provisions: an empirical study of IT services contracts. Organ. Sci. 18 (1), 3-19.

Ariño, A., de la Torre, J., 1998. Learning from failure: towards an evolutionary model of collaborative ventures. Organ. Sci. 9 (3), $306-325$.

Ariño, A., Ragozzino, R., Reuer, J.J., 2008. Alliance dynamics for entrepreneurial firms. J. Manag. Stud. 45 (1), $147-168$.

Armstrong, J.S., Overton, T.S., 1977. Estimating nonresponse bias in mail surveys. J. Market. Res. 14 (3), $396-402$.

Balakrishnan, S., Koza, M.P., 1993. Information asymmetry, adverse selection, and joint ventures. J. Econ. Behav. Organ. 20, 99-117.

Beamish, P.W., Inkpen, A.C., 1995. Keeping international joint ventures stable and profitable. Long. Range Plan. 28 (3), $26-36$.

Bercovitz, J., Jap, S.D., Nickerson, J.A., 2006. The antecedents and performance implications of cooperative exchange norms. Organ. Sci. 17 (6), 724-740.

Björkman, I., 1995. The board of directors in Sino-Western joint ventures. Corp. Govern. Int. Rev. 3 (3), 156-166.

Bleeke, J., Ernst, D., 1991. The way to win in cross-border alliances. Harv. Bus. Rev. 69 (6), 127-135.

Borys, B., Jemison, D.B., 1989. Hybrid arrangements as strategic alliances: theoretical issues in organizational combinations. Acad. Manag. Rev. 14 (2), 234-249.

Bradach, J.L., Eccles, R.G., 1989. Price, authority, and trust: from ideal types to plural forms. Annu. Rev. Sociol. 97-118.

Cao, Z., Lumineau, F., 2015. Revisiting the interplay between contractual and relational governance: a qualitative and meta-analytic investigation. J. Oper. Manag. 33, $15-42$.

Carson, S.J., Madhok, A., Wu, T., 2006. Uncertainty, opportunism, and governance: the effects of volatility and ambiguity on formal and relational contracting. Acad. Manag. J. 49 (5), 1058-1077.

Carson, S.J., 2007. When to give up control of outsourced new product development. J. Market. 71 (1), 49-66.

Chi, T., 1994. Trading in strategic resources: necessary conditions, transaction cost problems, and choice of exchange structure. Strat. Manag. J. 15, 271-290.

Child, J., 2001. Learning through strategic alliances. In: Handbook of Organizational Learning and Knowledge, pp. 657-680.

Cohen, M.D., Bacdayan, P., 1994. Organizational routines are stored as procedural memory: evidence from a laboratory study. Organ. Sci. 5 (4), 554-568.

Crocker, K.J., Masten, S.E., 1991. Pretia ex machine? Prices and process in long-term contracts. J. Law Econ. 34 (1), 69-99.

Crocker, K.J., Reynolds, K.J., 1993. The efficiency of incomplete contracts: an empirical analysis of Air Force engine procurement. Rand J. Econ. 24 (1), 126-146.

Cyert, R.M., March, J.G., 1963. A Behavioral Theory of the Firm. Englewood Cliffs, NJ 2.

Das, T.K., Teng, B.S., 1998. Between trust and control: developing confidence in partner cooperation in alliances. Acad. Manag. Rev. 23 (3), $491-512$.

Deeds, D.L., Hill, C.W., 1999. An examination of opportunistic action within research alliances: evidence from the biotechnology industry. J. Bus. Ventur. 14 (2), 141-163.

Dhanaraj, C., Beamish, P.W., 2004. Effect of equity ownership on the survival of international joint ventures. Strat. Manag. J. 25 (3), $295-305$.

Dillman, D., 2007. In: Hoboken, N.J. (Ed.), Mail and Internet Surveys: the Tailored Design Method 2007, Update with New Internet, Visual, and Mixed-method Guide, second ed. John Wiley and Sons.

Doz, Y.L., 1996. The evolution of cooperation in strategic alliances: initial conditions or learning processes? Strat. Manag. J. 17 (S1), 55-83.

Dussauge, P., Garrette, B., Mitchell, W., 2004. Asymmetric performance: the market share impact of scale and link alliances in the global auto industry. Strat. Manag. J. 25 (7), 701-711.

Dyer, J.H., Singh, H., 1998. The relational view: cooperative strategy and sources of interorganizational competitive advantage. Acad. Manag. Rev. 23 (4), 660-679.

Faems, D., Janssens, M., Madhok, A., Van Looy, B., 2008. Toward an integrative perspective on alliance governance: connecting contract design, trust dynamics, and contract application. Acad. Manag. J. 51 (6), 1053-1078.

Feldman, M.S., Rafaeli, A., 2002. Organizational routines as sources of connections and understandings. J. Manag. Stud. 39 (3), $309-331$.

Felin, T., Foss, N.J., Heimeriks, K.H., Madsen, T.L., 2012. Microfoundations of routines and capabilities: individuals, processes, and structure. J. Manag. Stud. 49 (8), 1351-1374.

Fudenberg, D., Levine, D., Maskin, E., 1994. The folk theorem with imperfect public information. Econometrica. Journal of the Econometric Society 997-1039. 
Garen, J., 1984. The Returns to Schooling: a selectivity bias approach with a continuous choice variable. Econometrica 52 (5), $1199-1218$. Geringer, J.M., Hébert, L., 1989. Control and performance of international joint ventures. J. Int. Bus. Stud. 20 (2), $235-254$. Geyskens, I., Steenkamp, J.B.E., Kumar, N., 2006. Make, buy, or ally: a transaction cost theory meta-analysis. Acad. Manag. J. 49 (3), $519-543$. Ghoshal, S., Moran, P., 1996. Bad for practice: a critic of the transaction cost theory. Acad. Manag. Rev. 21 (1), $13-47$.

Gil, R., 2009. Revenue sharing distortions and vertical integration in the movie industry. J. Law Econ. Organ. 25 (2), 579-610.

Golden, B.R., 1992. The past is the past-or is it? The use of retrospective accounts as indicators of past strategy. Acad. Manag. J. 35 (4), $848-860$.

Gong, Y., Shenkar, O., Luo, Y., Nyaw, M.K., 2007. Do multiple parents help or hinder international joint venture performance? The mediating roles of contract completeness and partner cooperation. Strat. Manag. J. 28, 1021-1034.

Greene, W.H., 2007. Econometric Analysis, sixth ed. Prentice Hall, Upper Saddle River, NJ.

Gulati, R., 1995. Does familiarity breed trust? The implications of repeated ties for contractual choice in alliances. Acad. Manag. J. 38, 85-112.

Gulati, R., Singh, H., 1998. The architecture of cooperation: managing coordination costs and appropriation concerns in strategic alliances. Adm. Sci. Q. 43, 781-814.

Gulati, R., Lawrence, P.R., Puranam, P., 2005. Adaptation in vertical relationships: beyond incentive conflict. Strat. Manag. J. 26 (5), $415-440$.

Gulati, R., Sytch, M., 2008. Does familiarity breed trust? Revisiting the antecedents of trust. Manag. Decis. Econ. 29 (2-3), 165-190.

Harman, H.H., 1967. Modern Factor Analysis. University of Chicago Press, Chicago, IL.

Harrison, J.S., Hitt, M.A., Hoskisson, R.E., Ireland, R.D., 2001. Resource complementarity in business combinations: extending the logic to organizational alliances. J. Manag. 27 (6), 679-690.

Hart, O., Holmstrom, B., 1987. The theory of contracts. In: Bewley, T. (Ed.), Advances in Economic Theory: Fifth World Congress.

Hart, O., Moore, J., 1988. Incomplete contracts and renegotiation. Econometrica. Journal of the Econometric Society 755-785.

Hart, O., 1995. Firms, Contracts, and Financial Structure. Clarendon Press.

Harzing, A.W., 2002. Acquisitions versus greenfield investments: international strategy and management of entry modes. Strat. Manag. J. 23 (3), $211-227$.

Heimeriks, K.H., Duysters, G., 2007. Alliance capability as a mediator between experience and alliance performance: an empirical investigation into the alliance capability development process. J. Manag. Stud. 44 (1), 25-49.

Heimeriks, K., Klijn, E., Reuer, J., 2009. Building capabilities for alliance portfolios. Long. Range Plan. 42 (1), $96-114$.

Helleloid, D., Simonin, B., 1994. Organizational learning and a firm's core competence. Competence-based competition 5, $213-239$.

Hennart, J.F., 1988. A transaction costs theory of equity joint ventures. Strat. Manag. J. 9 (4), 361-374.

Hennart, J.F., Kim, D.J., Zeng, M., 1998. The impact of joint venture status on the longevity of Japanese stakes in US manufacturing affiliates. Organ. Sci. 9 (3), $382-395$

Hewitt, I., 2005. Joint Ventures, fifth ed. Sweet \& Maxwell.

Hoang, H., Rothaermel, F.T., 2005. The effect of general and partner-specific alliance experience on joint R\&D project performance. Acad. Manag. J. 48 (2), 332-345.

Hoetker, G., 2007. The use of logit and probit models in strategic management research: critical issues. Strat. Manag. J. 28 (4), $331-343$.

Hoetker, G., Mellewigt, T., 2009. Choice and performance of governance mechanisms: matching alliance governance to asset type. Strat. Manag. J. 30 (10), 1025-1044.

Huang, C., Shields, T.G., 2000. Interpretation of interaction effects in logit and probit analyses - reconsidering the relationship between registration laws, education, and voter turnout. American Political Research 28 (1), 80-95.

Jap, S.D., Anderson, E., 2003. Safeguarding interorganizational performance and continuity under ex post opportunism. Manag. Sci. 49 (12), 1684-1701.

Janger, A.R., 1980. Organization of International Joint Ventures 1 University of Michigan-Dearborn No. 2.

Joskow, P.L., 1988. Asset specificity and the structure of vertical relationships: empirical evidence. J. Law Econ. Organ. 4 , $95-117$.

Kale, P., Singh, H., 2007. Building firm capabilities through learning: the role of the alliance learning process in alliance capability and firm-level alliance success. Strat. Manag. J. 28 (10), 981-1000.

Kale, P., Singh, H., Perlmutter, H., 2000. Learning and protection of proprietary assets in strategic alliances: building relational capital. Strat. Manag. J. 21 (3), $217-237$.

Killing, J., 1983. Strategies for Joint Ventures. Praeger, New York, NY.

Kim, P., 1997. When what you know can hurt you: a study of experiential effects on group discussion and performance. Organ. Behav. Hum. Decis. Process. 69, 165-177.

Klein, B., Crawford, R.G., Alchian, A.A., 1978. Vertical integration, appropriable rents, and the competitive contracting process. J. Law Econ. 21 (2), 297-326.

Klein, B., 1980. Transaction cost determinants of" unfair" contractual arrangements. Am. Econ. Rev. 70 (2), 356-362.

Klijn, E., Reuer, J.J., Van den Bosch, F.J., Volberda, H.W., 2013. Performance implications of IJV boards: a contingency perspective. J. Manag. Stud. 50 (7), $1245-1266$.

Kogut, B., 1988. Joint ventures: theoretical and empirical perspectives. Strat. Manag. J. 9 (4), 319-332.

Krishnan, R., Martin, X., Noorderhaven, N., 2006. When does trust matter to alliance performance? Acad. Manag. J. 49, 894-917.

Kumar, S., Seth, A., 1998. The design of coordination and control mechanisms for managing joint venture parent relationships. Strat. Manag. J. 19 (6), 579-599.

Kumar, N., Stern, L.W., Anderson, J.C., 1993. Conducting interorganizational research using key informants. Acad. Manag. J. 36 (6), $1633-1651$.

Larson, A., 1992. Network dyads in entrepreneurial settings: a study of the governance of exchange relationships. Adm. Sci. Q. 76-104.

Lenox, M., King, A., 2004. Prospects for developing absorptive capacity through internal information provision. Strat. Manag. J. 25 (4), 331-345.

Lewicki, R.J., Bunker, B.B., 1996. Developing and maintaining trust in work relationships. Trust in organizations: Frontiers of theory and research 114, 139.

Li, D., Eden, L., Hitt, M.A., Ireland, R.D., Garrett, R.P., 2012. Governance in multilateral R\&D alliances. Organ. Sci. 23, 1191-1210.

Lindell, M.K., Whitney, D.J., 2001. Accounting for common method variance in cross-sectional research designs. J. Appl. Psychol. 86 (1), 114.

Lioukas, C.S., Reuer, J.J., 2015. Isolating trust outcomes from exchange relationships: social exchange and learning benefits of prior ties in alliances. Acad. Manag. J. 58 (6), 1826-1847.

Llewellyn, K.L., 1931. What price contract?: an essay in perspective. Yale Law J. 40 (5), 704-751.

Lumineau, F., Malhotra, D., 2011. Shadow of the contract: how contract structure shapes interfirm dispute resolution. Strat. Manag. J. 32 (5), $532-555$.

Luo, Y., 2007. Are joint venture partners more opportunistic in a more volatile environment? Strat. Manag. J. 28 (1), 39-60.

Luo, Y., Park, S.H., 2004. Multiparty cooperation and performance in international equity joint ventures. J. Int. Bus. Stud. 35, 142-160.

Lyons, M., 1991. Joint-Ventures as strategic choice - a literature review. Long. Range Plan. 24 (4), $130-144$.

Lyons, B., Mehta, J., 1997. Contracts, opportunism and trust: self-interest and social orientation. Camb. J. Econ. 21 (2), $239-257$.

Macaulay, S., 1963. Use and nonuse of contracts in the manufacturing industry. The. Prac. Law. 9, 13.

Macneil, I.R., 1978. Essays on the nature of contract. NC Cent. Law Journal 10, 159.

Malhotra, D., Murnighan, J.K., 2002. The effects of contracts on interpersonal trust. Adm. Sci. Q. 47 (3), 534-559.

Malhotra, N.K., Kim, S.S., Patil, A., 2006. Common method variance in IS research: a comparison of alternative approaches and a reanalysis of past research. Manag. Sci. 52 (12), 1865-1883.

Malhotra, D., Lumineau, F., 2011. Trust and collaboration in the aftermath of conflict: the effects of contract structure. Acad. Manag. J. 54 (5), 981-998.

Masten, S.E., 1993. Transaction costs, mistakes, and performance: assessing the importance of governance. Manag. Decis. Econ. 14 (2), $119-129$.

Masten, S.E., 2002. Modern evidence on the firm. Am. Econ. Rev. 92 (2), 428-432.

Mayer, K., Argyres, N., 2004. Learning to contract: evidence from the personal computer industry. Organ. Sci. 15 (4), $394-410$.

McEvily, B., Perrone, V., Zaheer, A., 2003. Trust as an organizing principle. Organ. Sci. 14 (1), 91-103.

McKelvey, R.D., Zavoina, W., 1975. A statistical model for the analysis of ordinal level dependent variables. J. Math. Sociol. 4 (1), $103-120$.

Mellewigt, T., Madhok, A., Weibel, A., 2017. Trust and formal contracts in interorganizational relationships-substitutes and complements. Manag. Decis. Econ. 28 (8), 833-847.

Melnyk, S.A., Pagell, M., Jorae, G., Sharpe, A.S., 1995. Applying survival analysis to operations management: analyzing the differences in donor classes in the blood donation process. J. Oper. Manag. 13 (4), 339-356.

Meyer, K.E., Estrin, S., 2001. Brownfield entry in emerging markets. J. Int. Bus. Stud. 575-584.

Narasimhan, S., 1989. Relationship or boundary? Handling successive contracts. Calif. Manag. Rev. 77, $1077-1122$.

Nelson, R.R., Winter, S.G., 1982. The Schumpeterian tradeoff revisited. Am. Econ. Rev. 72 (1), 114-132. 
Osborn, R.N., Baughn, C.C., 1990. Forms of inter-organizational governance for multinational alliances. Acad. Manag. J. 33 (3), $503-519$.

Oxley, J.E., 1997. Appropriability hazards and governance in strategic alliances: a transaction cost approach. J. Law Econ. Organ. 13, 387-409.

Palay, T.M., 1984. Comparative institutional economics: the governance of rail freight contracting. J. Leg. Stud. 265-287.

Park, S.H., Ungson, G.R., 2001. Interfirm rivalry and managerial complexity: a conceptual framework of alliance failure. Organ. Sci. 12 (1), 37-53.

Parkhe, A., 1993. Strategic alliance structuring: a game theoretic and transaction cost examination of interfirm cooperation. Acad. Manag. J. 36 (4), 794-829.

Pisano, G.P., 1989. Using equity participation to support exchange: evidence from the biotechnology industry. J. Law Econ. Organ. 5, 109-126.

Podsakoff, P.M., MacKenzie, S.B., Lee, J.Y., Podsakoff, N.P., 2003. Common method biases in behavioral research: a critical review of the literature and recommended remedies. J. Appl. Psychol. 88 (5) 879-803.

Poppo, L., Zenger, T., 2002. Do formal contracts and relational governance function as substitutes or complements? Strat. Manag. J. 23 (8), $707-725$.

Poppo, L., Zhou, K.Z., Ryu, S., 2008. Alternative origins to interorganizational trust: an interdependence perspective on the shadow of the past and the shadow of the future. Organ. Sci. 19 (1), 39-55.

Poppo, L., Zhou, K.Z., Li, J.J., 2016. When can you trust "trust"? Calculative trust, relational trust, and supplier performance. Strat. Manag. J. 37 (4), 724-741.

Radner, R., 1986. Repeated partnership games with imperfect monitoring and no discounting. Rev. Econ. Stud. 53 (1), $43-57$.

Raheja, C.G., 2005. Determinants of board size and composition. A theory of corporate boards. J. Financ. Quant. Anal. 40, 283-306.

Rahman, N., Korn, H.J., 2014. Alliance longevity: examining relational and operational antecedents. Long. Range Plan. 47 (5), 245.

Ravasi, D., Zattoni, A., 2006. Exploring the political side of board involvement in strategy: a study of mixed-ownership institutions. J. Manag. Stud. 43, 1671-1702.

Reuer, J.J., Ariño, A., 2002. Contractual renegotiations in strategic alliances. J. Manag. 28 (1), 47-68.

Reuer, J.J., Zollo, M., Singh, H., 2002. Post-formation dynamics in strategic alliances. Strat. Manag. J. 23, 135-151.

Reuer, J.J., Ariño, A., 2007. Strategic alliance contracts: dimensions and determinants of contractual complexity. Strat. Manag. J. 28, 313-330.

Reuer, J.J., Klijn, E., Lioukas, C.S., 2014. Board involvement in international joint ventures. Strat. Manag. J. 35 (11), $1626-1644$.

Reuer, J.J., Klijn, E., 2018. Governance of hybrid organizations. Annals of Corporate Governance 3 (1), 1-81.

Ring, P.S., Van de Ven, A.H., 1992. Structuring cooperative relationships between organizations. Strat. Manag. J. 13 (7), $483-498$.

Rousseau, D.M., Sitkin, S.B., Burt, R.S., Camerer, C., 1998. Not so different after all: a cross-discipline view of trust. Acad. Manag. Rev. 23 (3), $393-404$.

Ryall, M.D., Sampson, R.C., 2009. Formal contracts in the presence of relational enforcement mechanisms: evidence from technology development projects. Manag. Sci. 55, 906-925.

Satorra, A., Bentler, P.M., 2001. A scaled difference chi-square test statistic for moment structure analysis. Psychometrika 66 (4), $507-514$.

Saussier, S., 2000. Transaction costs and contractual incompleteness: the case of Électricité de France. J. Econ. Behav. Organ. 42 (2), $189-206$.

Schaan, J.L.F., Beamish, P.W., 1988. Joint venture general managers in developing countries. In: Cooperative Strategies in International Business. Lexington Books, Heath \& Co, Lexington, MA.

Schepker, D.J., Oh, W.Y., Martynov, A., Poppo, L., 2014. The many futures of contracts: moving beyond structure and safeguarding to coordination and adaptation. J. Manag. 40 (1), 193-225.

Shenkar, O., Zeira, Y., 1992. Role conflict and role ambiguity of chief executive officers in international joint ventures. J. Int. Bus. Stud. 23 (1), 55-75.

Silverman, B.S., Nickerson, J.A., Freeman, J., 1997. Profitability, transactional alignment, and organizational mortality in the US trucking industry. Strat. Manag. J. 18, $31-52$.

Simonin, B.L., 1997. The importance of collaborative know-how: an empirical test of the learning organization. Acad. Manag. J. 40 (5), $1150-1174$.

Solís-Rodríguez, V., González-Díaz, M., 2018. Prior interactions and contractual completeness in Spanish franchising. Small Bus. Econ. 1-18.

Tirole, J., 1986. Procurement and renegotiation. J. Polit. Econ. 94 (2), 235-259.

Uzzi, B., 1997. Social structure and competition in interfirm networks: the paradox of embeddedness. Adm. Sci. Q. 35-67.

Vanneste, B.S., Puranam, P., 2010. Repeated interactions and contractual detail: identifying the learning effect. Organ. Sci. 21 (1), $186-201$.

White, S., Siu-Yun Lui, S., 2005. Distinguishing costs of cooperation and control in alliances. Strat. Manag. J. 26 (10), 913-932.

Williamson, O.E., 1975. Markets and Hierarchies. New York. pp. 26-30.

Williamson, O.E., 1985. The Economic Institutions of Capitalism: Firms, Markets and Relational Contracting. Free Press, New York.

Williamson, O.E., 1991. Comparative economic organization: the analysis of discrete structural alternatives. Adm. Sci. Q. 269-296.

Yermack, D., 1996. Higher market valuation of companies with a small board of directors. J. Financ. Econ. 40 (2), $185-211$.

Zaheer, A., McEvily, B., Perrone, V., 1998. Does trust matter? Exploring the effects of interorganizational and interpersonal trust on performance. Organ. Sci. 9 (2), 141-159.

Zahra, S.A., Pearce, J.A., 1989. Boards of directors and corporate financial performance: a review and integrative model. J. Manag. 15 (2), 291-334.

Zollo, M., Reuer, J.J., Singh, H., 2002. Interorganizational routines and performance in strategic alliances. Organ. Sci. 13 (6), $701-713$.

Dr. Valérie Duplat Valérie is an Assistant Professor of Strategic Management at the Vrije Universiteit Amsterdam. Valérie graduated with a Ph.D. in Strategic Management from the Catholic University of Louvain, Belgium. Her research interests are in contract design and dispute resolutions in technology-oriented inter-firm partnerships and joint ventures. In June 2013, Valérie obtained a Junior Faculty Award granted by the FNEGE (French Foundation for Management Education). Her work has been published in Research Policy, Managerial and Decision Economics, Small Business Economics and M@n@gement.

Dr. Elko Klijn Elko is an Assistant Professor of Strategic Management at the Old Dominion University. Elko graduated with a Ph.D. in Strategic Management from the University of Leeds, the United Kingdom. His research focuses on governance in strategic alliances and more particular on board of directors in joint ventures. In this strand of research he focuses on board composition, board tasks and how these characteristics and responsibilities influence alliances outcomes. His work has appeared in academic journals such as the Strategic Management Journal, Global Strategy Journal, British Journal of Management, and Journal of Management Studies as well as practitioner oriented outlets such as Long Range Planning, and the European Business Review. Elko is also a co-editor of a book on alliance governance.

Prof. Dr. Jeffrey Reuer Jeffrey J. Reuer is the Guggenheim Endowed Chair and Professor of Strategy and Entrepreneurship at the University of Colorado. Professor Reuer has served as an Associate Editor for the Strategic Management Journal and as a Consulting Editor for the Journal of International Business Studies. He has served on the editorial boards of seventeen journals and has received five best reviewer awards. He serves on the Board of Directors of the Strategic Management Society (SMS). Professor Reuer's research uses organizational economics to investigate firms' external corporate development activities and growth options (e.g., strategic alliances, international joint ventures, acquisitions, and initial public offerings). Recent projects are on the governance and design of alliances, collaborative strategies, and applications of information economics and real options theory to various problems in strategy, international business, and entrepreneurship. He is a Fellow of the Strategic Management Society and was the first recipient of the SMS' Emerging Scholar Award. Managerial insights of his research have also appeared as articles and research briefings in the Harvard Business Review, MIT Sloan Management Review, Financial Times, and the Journal of Applied Corporate Finance.

Prof. Dr. Henri Dekker Henri Dekker is Professor of Management Control at the School of Business and Economics at Vrije Universiteit Amsterdam. Henri's research agenda is primarily focused on the themes of governance and control of interfirm relationships and management control within organizations. His work has been published in a variety of accounting and management journals. Henri currently is Associate Editor at Management Accounting Research and at Decision Sciences Journal, and serves on the editorial boards of Accounting, Organizations and Society, Behavioral Research in Accounting, European Accounting Review and Journal of Management Accounting Research. Henri received several awards for his research including the Notable contribution to the Management Accounting Literature Award in 2012 and Greatest Impact on Practice Award in 2010, both awarded by the American Accounting Association. 